\title{
Anne Tarvainen
}

\section{KÄHEYS}

\section{Laulajan äänenlaadun tarkastelua fysiologisesta, kokemuksellisesta ja kulttuurisesta näkökulmasta}

Tarkastelen tässä artikkelissa käheyttä lauluäänen piirteenä, joka näyttäytyy erilaisena eri yhteyksissä: sairauden oireena, likaisuutena, hälynä, tietynlaisena materiaalisena määreenä sekä osana laulajan tulkintaa ja tyyliä. Samalla puran käheyden käsitettä sen erilaisissa yhteyksissään. Tarkoituksena on luoda teoreettista pohjaa lauluäänen esteettisten piirteiden tutkimukselle, jossa otetaan huomioon lauluäänen laadut osana laulajan taiteellista ilmaisua. Samalla, kun lähestyn käheyden käsitettä, tuon myös esille erilaisia näkökulmia laulajaan ja kuulijaan ruumiillisina olentoina. Tarkastelemani käheyden määritelmät kytkeytyvät erilaisiin tapoihin määritellä ruumis. Kutsun näitä erilaisia ruumiskonstruktioita fysiologiseksi, kokemukselliseksi ja kulttuurisesti määräytyväksi ruumiiksi. Pohdin myös, miten nämä eri näkökulmat toimivat yhdessä tutkimuksen teoreettisena lähtökohtana ja millaista tietoa ne yhdessä tuottavat. Tutkijana liikun näkökulmasta toiseen tarkastellen lauluääntä toisinaan fysiologisesta näkökulmasta ja toisinaan suhteessa ympäröivään laulukulttuuriin tai tutkijan omaan kuuntelukokemukseen. Artikkelissa yhdistyy näin sekä luonnon- että ihmistieteisiin pohjautuvia käsityksiä siitä, miten ihmistä voidaan lähestyä ruumiillisena olentona'

Lähden liikkeelle puheentutkimuksen ${ }^{2}$ tarjoamasta tiedosta, joka kytkee käheyden fysiologiseen ruumiiseen. Tuon esille puheentutkimuksessa esitettyjä käsityksiä siitä, millaisena käheys konkretisoituu, mistä siinä on materiaalin (kudosten) tasolla kyse. Tämän tutkimuskentän tarjoaman "hygieenisen äänen" käsitteen kautta siirryn tarkastelemaan käheyttä Mary Douglasin likaisuuteen liittyvien antropologisten pohdintojen viitoittamasta näkökulmasta. Sivuan käheyttä myös äänessä olevana kohinana kommunikaation näkökulmasta. Viimeksi mainituissa tarkasteluissa tuon esille joitakin fysiologiseen ruumiiseen liittyvän käheyden kulttuurisia merkityksiä. Tämän jälkeen pohdin käheyden kokemuksellista laatua: millaisiin materiaalisiin määreisiin se liittyy aistimisessamme? Tässä tarkastelussa tuon esille musikologi/lingvisti Theo van Leeuwenin ajatuksia aistienvälisyydestä. Käsittelen käheyttä myös omassa työssäni olennaisen "äänen virtauksen" käsitteen kannalta, jonka avulla kytken äänenlaadut kokemukselliseen ruumiiseen. Analyysiesimerkin avulla tuon esille käheyden osana 
laulajan tulkintaa. Seuraavaksi pohdin käheyttä ja kulttuurisesti määräytyvää ruumista Alan Lomaxin maailman laulutyylejä käsittelevän tutkimuksen valossa sekä joidenkin uudempien, populaarimusiikin laulamiseen keskittyvien tarkastelujen valossa. Lopuksi pohdin, missä määrin käheys on laulajan valittavissa ja missä määrin se on materiaalinen tai kulttuurinen pakko.

Olen valinnut tähän artikkeliin äänenlaaduista juuri käheyden, koska se liittyy olennaisesti joihinkin populaarimusiikin laulutyyleihin ja varsinkin tiettyjen artistien laulutyyleihin ja -tulkintoihin. Lisäksi käheys on siinä mielessä mielenkiintoinen äänenlaadullinen käsite, että se on tyypillinen sairaaksi ääneksi luokitellun äänen piirre. Artikkelini yhtenä tavoitteena onkin pohtia tätä tutkimuksessani ${ }^{3}$ olevaa perustavanlaatuista ristiriitaa: tutkin käheitä ääniä väittäen, että käheys voi olla osa taiteellista ilmaisua ja tutkin näitä ääniä käyttäen apunani menetelmiä, jotka on kehitetty tunnistamaan äänen käheys juuri sairauden oireena. Artikkelini tarkoituksena ei ole kuitenkaan kiistää käheyttä äänen ongelmana tai sairautena, vaan laajentaa käheyden tarkastelu koskemaan myös sen funktiota laulajan tulkinnan ja tyylin rakentajana. Käheys on käsitteenä mielenkiintoinen myös siksi, että se ei ole äänifysiologiankaan kannalta yksiselitteinen: käsitteen alle mahtuu hyvin mónenlaista käheyttä. Valaisen kysymystä käheydestä myös muutamien eri näkökulmista tekemieni analyysien avulla. Käytän esimerkkinä islantilaislaulaja Björkin ääntä hänen Vespertine-levyn Hidden Place -kappaleessaan (Björk 2001).

\section{Sairas ääni}

Puheentutkimuksen kentällä käheys määrittyy sairaan tai huonosti tuotetun äänen piirteeksi. Suurin osa alan analyysimenetelmistä on kehitetty terapeuttisiin tarkoituksiin. Menetelmien avulla pyritään selvittämään ääniongelmien syitä ja sitä, millaisella hoidolla ongelmia voidaan helpottaa. Näiden menetelmien avulla ei ole siis alun perin ollut tarkoitus selvittää lauluäänen taiteelliseen ilmaisuun liittyviä esteettisiä seikkoja, joskin menetelmiä on sittemmin käytetty myös lauluäänten esteettisten piirteiden analyysiin niin vokologian kuin esimerkiksi etnomusikologiankin piirissä. ${ }^{4}$ Puheentutkimuksessa äänenlaatua voidaan lähestyä kuunteluanalyysin tai akustisten tutkimusmenetelmien ${ }^{5}$ avulla. Keskityn tässä artikkelissa kuunteluanalyysiin, koska se on lähestymistapa omassa työssäni.

Puhetekniikkaan liittyvässä kuunteluanalyysissa yksi keskeinen tekijä on huomion kiinnittäminen äänen mahdolliseen käheyteen. Anne-Maria Laukkanen ja Timo Leino opastavat kirjassaan Ihmeellinen ihmisääni (2001: 202), että äänenlaadun arvioinnissa tulee kiinnittää huomiota siihen, onko ääni jatkuvasti käheä, vai onko mukana ajoittain kirkasta ja soivaa ääntä. Jos ääni on ajoittain kirkas, kyseessä saattaa olla terve, huo- 
nosti tuotettu ääni. Jos ääni on puolestaan koko ajan käheä, se luokitellaan sairaaksi. Laukkanen ja Leino erottavatkin toisistaan normaalin, joskin huonon äänen ja sairaan (patologisen) äänen. Jälkimmäisen yksi keskeisiä piirteitä on äänessä kuuluva käheys. (Laukkanen ja Leino 2001: 202) Osa äänentuottamiseen liittyvistä ongelmista voidaan korjata terapian ja harjoitusten avulla, osa ongelmista puolestaan johtuu fysiologisista vammoista tai sairauksista, joille ihminen ei itse voi mitään. Käheys voi aiheutua muun muassa äänihuulten kyhmyistä tai halvautumisesta (Laukkanen ja Leino 2001: 176-178) ja esimerkiksi kurkunpääsyövän tyypillinen oire on käheys (Grénman 1999: 216). Äänihuulten limakalvon värähtelevässä osassa oleva ylimääräinen massa (esimerkkejä kuvassa 1) aiheuttaa äänihuulten värähtelysyklin epäsäännöllisyyden ja haittaa ääniraon tiivistä sulkeutumista. Näiden seurauksena äänenlaatu muuttuu käheäksi. (Rihkanen 1999: 212.)
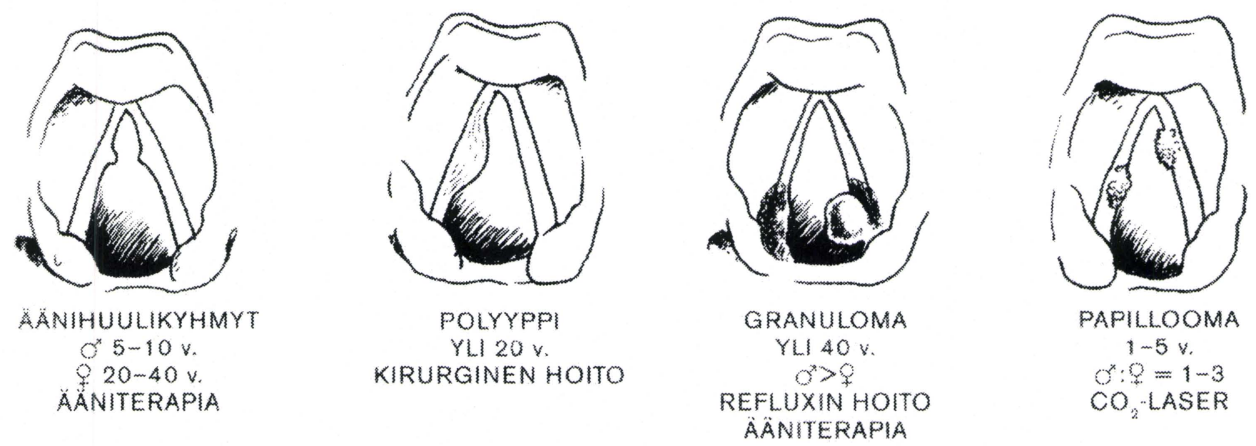

Kuva 1: Tavallisimmat äänihuulten hyvänlaatuiset muutokset. (Rihkanen 1999: 213)

Laukkanen ja Leino määrittelevät käheyden äänen suureksi hälypitoisuudeksi. Heidän mukaansa käheässä äänessä on kuultavissa kuiskaushälyä. Lisäksi äänihuulet värähtelevät epäsäännöllisesti, mikä aiheuttaa ääneen pienen perustaajuuden vaihtelun. Tämä voi ilmetä äänen rahisemisena tai raakkumisena. (Laukkanen ja Leino 2001: 176-178, 202) John Laver on heidän kanssaan samoilla linjoilla. Hän määrittelee kirjassaan The Phonetic Description of Voice Quality (1980: 133) käheän äänen ääneksi, joka on yhtä aikaa sekä karkea että kuiskaava (harsh whispery voice). Hän tuo esille karkean äänen akustisia piirteitä eri tutkijoiden määritteleminä. Karkean äänen spektrissä on havaittavissa säännöttömyyttä ja epäperiodista hälyä tai kohinaa. Useimmissa esitellyissä määrittelyissä toistuvatkin termit säännöttömyys (irregularity), epäperiodisuus (aperiodicity) ja häly (noise). (Laver 1980: 127) Kuiskaavassa äänessä äänihuulet jäävät osittain auki ja ilmaa pääsee karkaamaan niiden välistä. Ilman kulku tarpeeksi suurella paineella äänihuulten muodostamasta kapeikosta aiheuttaa hälyä, josta on seurauksena "kuiskaava" äänenlaatu. 
Käheys ei kuitenkaan välttämättä johdu äänihuulten fysiologisista muutoksista, vaan käheyttä voi tuottaa ääneen tai sitä voi tulla ääneen myös äänihuulten tavasta värähdellä epäsäännöllisesti. Grayn ja Wisen mukaan karkeuden voidaan katsoa liittyvän monissa tapauksissa kurkun ja niskan jännittyneisyyteen, joka puolestaan voi liittyä koko ruumiin jännittyneisyyteen (Gray \& Wise 1959, sit. Laver 1980: 129). Karkeus on yleisempää matalissa äänissä ja se voi olla myös seurausta liian matalasta äänenkäytöstä (Van Riper \& Irwin 1958: 232 ja Zemlin 1964: 165, sit. Laver 1980: 129). Myös kuiskaavuuteen liittyy usein kurkunseudun jännittyneisyys kuten karkeuteenkin. Laver tuo myös esille muutamien tukijoiden toteamuksen, jonka mukaan kuiskaavuudessa on kyse ilmavirran erittäin epäekonomisesta käytöstä. (Laver 1980: $120-121$ ja $133-134)^{6}$

Puheentutkimuksen piirissä äänenlaatua on tarkasteltu hyvin konkreettisesti ruumiiseen ja sen liikkeisiin sidottuina. Taustalla on tieto ihmisen fysiologiasta. Tiedetään, miten äänihuulet, ääniväylä, pallea jne. toimivat ääntä tuotettaessa. Äänen laadusta puheen tai laulun tutkija pystyy kuulemaan viitteitä siitä, mitä ruumiin sisäosissa tapahtuu - miten esimerkiksi äänihuulet värähtelevät toisiaan vasten, minkä tyyppistä niiden liike on. Puheentutkimuksen kentällä ruumis ja ääni hahmotetaan tavalla, joka on kytköksissä länsimaisen (lääke)tieteen rakentamaan ihmiskuvaan. Kutsun tämän hahmottamistavan mukaista ruumista fysiologiseksi ruumiiksi. Fysiologinen ruumis on myös kulttuurisesti määräytynyt, vaikka erotankin sen tässä työssä omaksi näkökulmakseen erotuksena antropologisten ja sosiologisten tieteiden kulttuurisesti määräytyvästä ruumiista. Luonteenomaista fysiologiselle ruumiille on mekaanisuus sen toimintaperiaatteena. Olennaista siinä on ruumiin pilkkominen pieniin "toimintayksiköihin" (esimerkiksi lihasryhmät ja yksittäiset elimet). Fysiologinen ruumis mielletään monesti myös instrumentiksi siinä mielessä, että ihminen voi "käyttää" sitä.

Fysiologinen ruumis lauluäänen esteettisten piirteiden kulttuurisensitiivisessä tutkimuksessa ei ole ongelmaton lähtökohta. Länsimaisen (lääke)tieteen konstruoimaa, mekaanisesti koneen lailla toimivaa ruumista on kritisoitu niin fenomenologisesta kuin sosiopoliittisestakin näkökulmasta (katso esimerkiksi Leder 1992: 4). Alexa Schriempf on eritellyt erilaisia näkökulmia lähestyä ruumiillisuutta artikkelissaan "(Re)fusing the Amputated Body" (2001), jossa hän käsittelee vammaisuutta feministisestä näkökulmasta. Hänen biologis-lääketieteellinen mallinsa tavoittaa samaa tasoa kuin tämän artikkelin fysiologisen ruumiin käsite. Lääketieteellisen mallin mukaan vammaisuus on sairaus, joka pitää minimoida tai korjata. Schriempf muistuttaa, että sosiaaliset standardit ylläpitävät vammaisuutta. Näihin standardeihin kuuluvat esimerkiksi käsitykset siitä, millaiselta hyvän ruumiin tulisi näyttää ja miten sen pitäisi käyttäytyä. (Schriempf 2001: 57-58.) Tästä voidaan vetää vertailukohtia myös käheyteen ja tämän hetken ihanteeseen siitä, millainen on terve ääni. ${ }^{7}$

Lauluäänen esteettisten piirteiden tutkijan tehtävä ei ole välttämättä ottaa kantaa siihen, onko lauluääni hänen mielestään terve vai sairas. Vaikka puheentutkimus 
käsitteleekin käheyttä äänen sairautena, voi laulun tutkija olla silti kiinnostunut käheydestä sinänsä, sen eri variaatioista ja ilmenemisistä tutkittavassa materiaalissa. Myös vokologian puolella erotetaan normatiivinen, äänenlaatua arvioiva ja toisaalta epänormatiivinen, äänen kuvailuun keskittyvä lähestymistapa (Laukkanen \& Leino 2001: 14). Puheentutkimus tarjoaa lauluäänen estetiikan tutkijalle hyviä luokitteluja ja termejä - työkaluja, joilla lähestyä esimerkiksi käheyden eri vivahteita. Se tarjoaa keinoja harjaannuttaa korvaa kuulemaan tarkemmin äänenlaadun eri muuttujia. ${ }^{8}$ Lisäksi puheentutkimuksen tarjoama tieto ruumiin sisäosien liikkeistä erilaisten äänenlaatujen tuottamisessa on hyvin mielenkiintoista, varsinkin kun tämän tiedon yhdistää laulajan äänenlaadun tehtävään musiikillisessa ilmaisussa.

Vaikka fysiologinen ruumis onkin saanut osakseen paljon kritiikkiä, näen sen kuitenkin yhtenä mahdollisena, lauluntutkijallekin hedelmällisenä näkökulmana ihmisruumiiseen ja laulamiseen. Puheentutkimus on tuottanut ihmisäänestä mielenkiintoista tietoa, jota ei tule suoralta kädeltä sivuuttaa. Pikemminkin on hyvä kysyä, miten tätä tietoa voi käyttää etnomusikologiselle lauluntutkimukselle sopivalla tavalla. Mielestäni tärkeään asemaan nousee myös toisen tieteenalan (puheentutkimuksen) tarjoaman tiedon tarkastelu kriittisesti pohtien, miten tämä tietämisen tapa ja siihen liittyvät tutkimusmenetelmät sopivat oman tieteenalamme lähtökohtiin ja käytäntöihin.

\section{Analyysi I: Björkin lauluäänen fysiologinen käheys}

Selventääkseni edellä esittelemääni fysiologiseen ruumiiseen liittyvää käheyden käsitettä analysoin lyhyen pätkän Björkin ääntä. Björk käyttää laulaessaan paljon erilaisia äänenlaatuja: käheyttä, narinaa, vuotoista ääntä ja niin edelleen. Painotan tässä sanaa "käyttää", koska Björkin äänen ei voi sanoa yksiulotteisesti olevan esimerkiksi käheä tai nariseva - hänen äänensä saattaa olla yhtenä hetkenä vuotoinen ja muuttua seuraavassa hetkessä narisevaksi ${ }^{9}$. Kyse on siis äänen toiminnallisesta käheydestä. "Käyttää" -sana toimii tässä yhteydessä myös siksi, että äänenlaatujen muutoksilla on Björkin tulkinnoissa merkityksenmuodostuksen kannalta tärkeä rooli (tästä lisää myöhemmin). Vespertine-levyllä selvää käheyttä esiintyy vain muutamissa kappaleissa ja niissäkin käheys on ajoittaista. Levyn ensimmäisessä kappaleessa Hidden Place Björk käyttää käheää ääntä kertosäkeissä. Esimerkiksi ensimmäisessä kertosäkeessä Björk laulaa ensimmäisen fraasin selkeällä äänellä korkeammalta ja toisen fraasin matalammalta käheällä äänellä. 

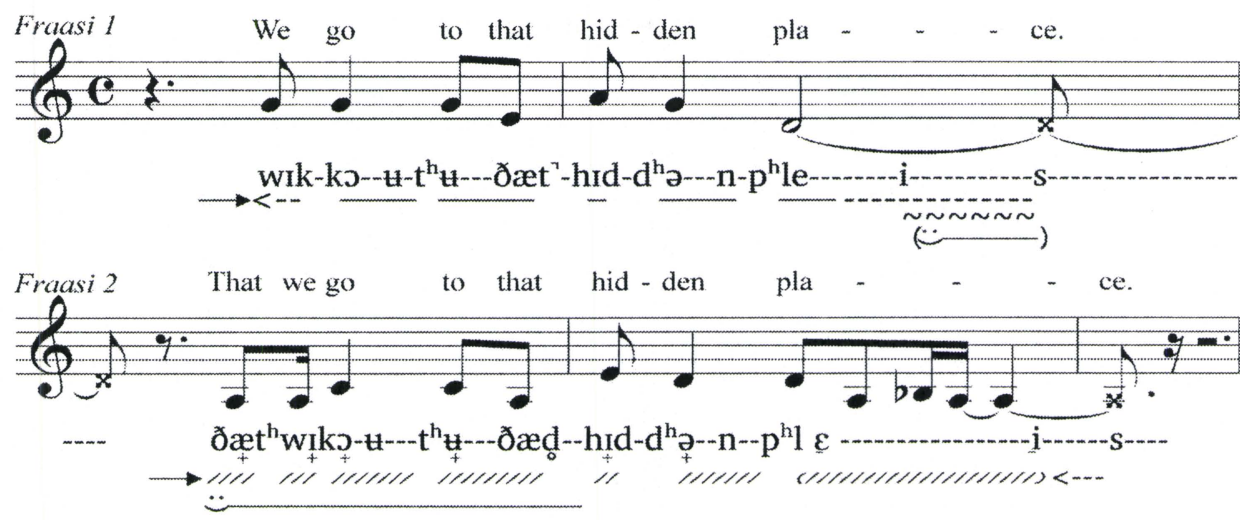

\section{Merkkien selitykset: \\ $\longrightarrow=$ kuuluva sisäänhengitys, <-- = ilman työntäminen tai valuminen ulos, $-=$ selkeä ääni,

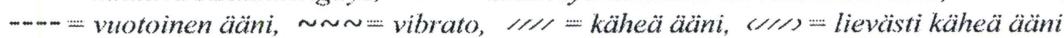 $\left({ }^{-}\right)=$kevyt hymynomainen ele, $\boldsymbol{H}^{-}=$hymynomainen ele.}

Kuva 2: Björkin lauluäänen ja äänteiden laatuja Hidden Place -kappaleen ensimmäisen kertosäkeen kahdessa ensimmäisessä fraasissa. Musiikillisen nuotinnoksen alla on foneettinen transkriptio ja sen alla äänenlaatuja kuvaavat merkinnät.

Kuten kuvasta 2 näkyy, ensimmäinen fraasi on suurimmaksi osaksi laulettu selkeällä äänellä lukuun ottamatta ensimmäisiä äänteitä, joiden aikana Björk työntää ilmaa ulos keuhkoistaan ja fraasin viimeisiä vokaaliäänteitä [e] ja [i], joiden aikana ääneen tulee mukaan vuotoisuutta ja hieman vibratoa. ${ }^{10}$ Toinen fraasi on puolestaan lähestulkoon kokonaan käheä. Tosin fraasin loppua kohti käheys heikkenee. Tämä voi johtua siitä, että Björk tarvitsee "tasaisemmin soivat äänihuulet" laulaakseen selkeämmin toisen fraasin toisen tahdin loppuosan melodiakuvion. Se on rytmisesti nopeampi ja sisältää pieniä intervalleja, joiden laulaminen vaatii enemmän tarkkuutta. Mainittakoon tässä, että kappaleen toisessa kertosäkeessä Björk laulaa vastaavan kohdan käheällä äänellä, jolloin melodia ja rytmi eivät ole yhtä täsmällisiä kuin ensimmäisessä kertosäkeessä. Foneettisista merkeistä" puolestaan näemme, että Björk laulaa ensimmäisen fraasin vokaalit hieman takaisempina ja avoimempina kuin toisen fraasin, jossa suuontelo tuntuu madaltuvan ja vokaalit työntyvät edemmäs (näitä muutoksia kuvaavat tässä transkriptiossa +-merkit). Vaikuttaa siltä, että tähän suuontelon madaltumiseen liittyy myös hymynomainen ele, joka kuuluu äänen värin muutoksena. Suuontelon supistuminen lähtee tapahtumaan jo ensimmäisen fraasin viimeisillä vokaaliäänteillä [e] ja [i]. Toisen fraasin vastaavat viimeiset vokaaliäänteet puolestaan ovat hivenen takaisempia ja väljempiä kuin ensimmäisessä fraasissa enteillen näin siirtymistä kertosäkeen kolmanteen fraasiin, joka on laulettu taas avoimemmin. 
Björkin äänen käheys tässä esimerkissä täyttää aiemmin esille tulleet käheyden tunnusmerkit hyvin. Äänessä on kuiskaushälyä ja äänihuulten epäsäännöllistä värähtelyä. Karkeus liittyy joidenkin tutkijoiden mielestä segmentaaliseen artikulaatioon. Esimerkiksi vokaalin karkeus voi lisääntyä, jos puhujalla on tapana lausua vokaalit avoimina, jos puhuja aloittaa vokaalinsa alukkeilla ja jos vokalisaatio on muutenkin äkkinäistä. (Laver 1980: 128.) Björkin esimerkissä puolestaan käy niin, että ääneen tulee käheyttä, kun Björk lausuu vokaalit suppeampina. Alukkeitakaan tässä esimerkissä ei ole, vaikka Björk niitä yleensä käyttääkin melko paljon. Laverin kirjasta selviää myös, että useimmat karkeat (puhe)äänet ovat sävelkorkeudeltaan matalia, lähellä puhujan rekisterin alaosaa. Intensiteetti on niissä usein voimakkaampi, kuin normaalissa äänessä. (Van Riper ja Irwin 1958: 232, sit. Laver 1980: 129.) Tässä esimerkissä Björkin ääneen käheys tuleekin niihin ääniin, jotka hän laulaa matalammalta. Ja vaikka Björk hakee mataliin ääniin kuiskaavuuden tuntua, hän laulaa äänet silti melko voimakkaalla intensiteetillä, joka on omiaan tuottamaan äänihuulten värähtelyyn epäsäännöllisyyttä.

\section{Likainen ääni}

Monet puheentutkimuksen alueet ovat keskittyneet löytämään ihanteellisen tavan tuottaa ääntä. Tässä yhteydessä käytetään termiä "hygieeninen"12 viittaamaan toimivaan äänentuottotapaan. Taustalla on pyrkimys oppia pois myötäsyntyisistä ja mahdollisesti vahingollisista tavoista käyttää ääntä. Tavoitteena on löytää taloudellinen, mahdollisimman vähällä lihastyöllä toimiva pitkää rasitusta kestävä ja ilmaisuvoimainen ääni. Ajatuksena on tarkoituksenmukaisuus niin ymmärrettävyyden, ilmaisuvoiman kuin fysiologisen taloudellisuudenkin näkökulmasta. (Laukkanen \& Leino 2001: 15, 18, 21.)

Voimme tarkastella pyrkimystä hygieeniseen äänentuottoon myös toisenlaisesta näkökulmasta. Antropologi Mary Douglas (2000) pohtii hygieniahoitoa teoksessaan Puhtaus ja vaara - ritualistisen rajanvedon analyysi. Hän toteaa, ettei likaa sinällään ole olemassakaan. Se on pohjimmiltaan epäjärjestystä. Lian poistaminen on Douglasin mukaan positiivinen yritys luoda järjestystä ympäristöön. (mts.: 47.) Vaikka puheentutkimuksessa ei puhutakaan konkreettisesti liasta epähygieenisen äänentuoton yhteydessä, voi pyrkimyksen "puhtaaseen" ääneen nähdä juuri Douglasin esittämänä pyrkimyksenä järjestykseen. Tässä tapauksessa voidaan ajatella, että kyseessä on ruumiin ja kommunikoinnin (puheen, laulun) järjestäminen kulttuurisesti sopiviksi. Ja mikä sopisikaan paremmin kulttuuriimme kuin selkeys ja tehokkuus. Kontrolloimaton käheys näyttäytyy länsimaiselle ihmiselle helposti epämiellyttävänä.

Käheys ei näyttäydy epämiellyttävänä pelkästään länsimaisessa kontekstissa. Tuhansia vuosia vanhat intialaiset kirjoituksetkin mainitsevat käheyden epätoivottuna äänen piirteenä. Intialaisessa vedakirjallisuudessa jo $500 \mathrm{eKr}$. esiintyy erilaisia 
(lähinnä toiminnallisia) äänihäiriöitä, kuten esimerkiksi käheys, äänen huojunta, äänen hiljainen voimakkuus, nasaalisuus, epäselvä artikulaatio, falsetti, kuuluvat rekisterinvaihdokset ja nuotin vierestä laulaminen. Durga (1983) esittelee näitä käsityksiä artikkelissaan "Indian Literature on Vocal Abuse". Intialaisessa perinteessä oikeanlainen äänenkäyttö on liittynyt Durgan mukaan erilaisten jumalien palvontaan hymnejä laulamalla. Tietty jumala esiintyi oikein soivan hymnin ilmaisussa ja hymnit itsessään olivat pyhiä. Väärin resitoitu hymni puolestaan ei ollut voimallinen, eikä tuottanut toivottuja tuloksia. Durga kirjoittaa: "On todellakin merkillepantavaa, että nämä ongelmat ansaitsivat merkittävää huomiota tuhansia vuosia ennen tieteellisen ajan alkua, ja että heidän huomionsa äänihäiriöistä perustuvat varmaan näkemykseen ja intuitioon, joka toisaalta on selitettävissä modernin tieteen ymmärrettävällä terminologialla." (Durga 1983: 1-3, 8)

Vanhoissa intialaisissa ja nykyisissä länsimaisissa äänentuoton ihanteissa löytyy yhtenevyyksiä, mutta syyt, miksi näihin ihanteisiin pyritään, eroavat toisistaan. Tässä on nähtävissä samoja piirteitä kuin Douglasin pohdinnoissa hygieniasta, joissa hän vertaa "taikauskoisia" muiden (primitiivisten) kulttuurien hygieniakäsityksiä länsimaisiin "rationaalisiin" käsityksiin. Näissä käsityksissä itse tavat toimia ovat pitkälti samanlaisia, mutta selitykset ja syyt eroavat toisistaan - toisessa käyttäytymistä selitetään uskonnolla ja toisessa hygieniaopilla. Douglas toteaakin, että myös meidän hygieenisyyskäsityksemme ilmaisevat symbolisia järjestelmiä yhtä lailla kuin muidenkin, vaikka ne meillä eivät liittyisikään uskontoomme. ${ }^{13}$ (Doủglas 2000: 82, 85.)

Douglas tuo myös esille, että yhteiskuntaa laajempana yksikkönä uhkaavat vaarat liittyvät kyseisessä kulttuurissa esillä oleviin ruumiillisiin teemoihin (Douglas 2000: 191). Mikä sitten on meidän yhteiskuntaamme uhkaava vaara, joka liittyy kommunikointiin niin, että kommunikointia (puhetta ja laulua) on järjesteltävä sopivaksi myös ruumiin tasolla? Tätä kysymystä voidaan lähestyä kohinan käsitteen avulla. Kai Eriksson (2003: 279) toteaa kohinan terminä viittaavan "johonkin sellaiseen, joka on suljettava ulos kommunikaatiosta, jotta yhteinen merkitys tulisi mahdolliseksi". Kohinan käsitteen avulla kuvaillaan sitä satunnaista, merkityksetöntä ja ristiriitaista, joka voisi häiritä ihmisten välistä yhteisymmärrystä (Eriksson 2003: 279). Eriksson kirjoittaa:

Kommunikaation historiassa on korostunut pyrkimys tunnistaa yhteinen koodi, muoto tai metodi. Tämä suojeli merkityksellistä kommunikaatiota väärinymmärrykseltä ja häirinnältä. Juuri yhteinen koodi asetti kommunikaation rajat sulkemalla ulos moneuden, joka alituisesti uhkasi peittää sen alleen. (Eriksson 2003: 279-280.) ${ }^{14}$

Voidaan siis ajatella, että ihmisäänen ollessa kyseessä epähygieenisyys ja kohina rinnastuvat keskenään - se, mikä on kommunikaatiossa kohinaa on ruumiin tasolla epähygieenistä. Liiallinen kohina, yhteisen koodin tuhoutuminen, voidaan nähdä yhteiskuntaamme laajempana yksikkönä uhkaavana vaarana ja tämä liittyy ruumiillisella 
tasolla kysymykseen äänen käyttämisestä ymmärrettävästi, tarkoituksenmukaisesti ja terveellisesti. Käheyden määritelmissähän kohtaavat "hälyn" sekä toisaalta "epähygieenisyyden" käsitteet.

Populaarimusiikin, varsinkin rockin laulaminen asettuu tässä käheyden tarkastelussa mielenkiintoiseen valoon. ${ }^{15}$ Rocklaulaja voi laulaa fyysisen sietokykynsä äärirajoilla piittaamatta tuon taivaallista äänensä hygieenisyydestä. Samaan tapaan hän voi pukeutua likaisiin farkkuihin ja olla pesemättä hiuksiaan välittämättä kulttuurimme yleisistä siisteysnormeista. Rockin rankemmat muodot ovat yhteiskuntaan kriittisesti, jopa anarkistisesti suhtautuvia taiteen muotoja, joiden kautta asetutaan yleisiä normeja vastaan. Samalla kuitenkin rockkulttuurien jäsenillä on omat norminsa: miltä äänen tulee kuulostaa, miten siitä tulee puhua, miten siihen suhtaudutaan ja niin edelleen. Attali toteaa että musiikin järjestys "simuloi sosiaalista järjestystä ja sen dissonanssit ilmentävät marginaaleja" (Attali 1977/1985: 29). Käheys voi näyttäytyä rockkulttuurin sisältä katsottuna normina, mutta se (dissonanssiluonteensa vuoksi) ainakin pyrkii asettumaan marginaaliin suhteessa ympäröivän kulttuurin ääni-ihanteisiin. Rocklaulannassa ikään kuin käytetään valtakulttuurin kommunikaation "ylijäämää" tai "jätettä" oman kommunikaation rakennusaineena. Se mikä oli merkityksetöntä tai häiritsevää nouseekin nyt merkitykselliseksi.

Myös puheentutkimuksen puolella on painotettu sitä, että ihmisääntä tulisi kuunnella aina tietoisena puhujan tai laulajan kulttuurisesta ja sosiaalisesta kontekstista. Se, että tietynlainen äänenkäyttö on epäsopivaa jossakin yhteydessä ei tarkoita, etteikö se soveltuisi johonkin toiseen yhteyteen. Näin ollen ideaalin äänenlaadun käsitekään ei ole yksiselitteinen. (Hollien 2000: 13) Ihanteellisen äänenkäytön objektiivinen määritteleminen onkin mahdotonta (Laukkanen \& Leino 2001: 14). Laukkanen ja Leino kirjoittavat:

\footnotetext{
Eri kulttuureissa ja meidänkin kulttuurimme sisällä on paljon erilaisia äänenkäyttötapoja, joita voidaan asettaa äänihygieenisessä mielessä erilaiseen järjestykseen. Rocklaulajan rankan puristeisen äänenkäyttötavan seurauksena saattavat olla esimerkiksi äänihuulikyhmyt. Rocklaulutyylin ilmaisuarvoa ei kuitenkaan voida kiistää, eikä se ehkä ole korvattavissa millään äänihygieenisemmällä tyylillä. Silti rocklaulajallekin tieto äänensuojelusta on hyödyksi. Hän voi sen perusteella ottaa riskinsä tietoisesti ja pyrkiä suojelemaan työvälinettään minimoimalla äänellisen rasituksen konserttilavan ja äänitysstudion ulkopuolella[.](Laukkanen \& Leino 2001: 21.)
}

Erilaisten laulutyylien ilmaisuarvon ymmärtäminen on mielestäni tärkeää. Se, mikä voi olla toiselle laulajalle sairas tai pilalle mennyt ääni, voikin toisen laulajan mielestä olla saavutus, joka on vaatinut paljon ankaraa äänen "koulimista" esimerkiksi huutamalla ja tupakoimalla. Tärkeintä on se, miten laulaja toteuttaa äänellään asioita - ja miten hän itse selviää työstään laulajana äänensä kanssa. Mieleeni tulee Beth Gibbonsin, englantilaisesta Portishead-yhtyeestäkin tunnetun laulajan levy Out of Season (2002), jolla Gibbons laulaa hauraalla, särkyvällä, vuotoisella ja tupakoinnin 
runtelemalla äänellään tulkiten kappaleet hyvin vahvasti. Äänestä kuulee, että hän nauttii äänensä särähdyksistä ja huojumisista - tai ainakin hyväksyy ne osaksi ilmaisuaan ja kommunikointiaan. Tämän vuoksi laulutulkinnoista tulee vaikutelma, että niissä yhdistyvät sekä äänen "rikkinäisyys" että laulajan vapaus nauttia äänestään sellaisena kuin se on.

\section{Halkaistu ääni}

John Mowitt (1987: 194) kirjoittaa siitä, kuinka samalla, kun elektronisesti tuotettu taide on pyrkinyt eliminoimaan kohinan, se on radikalisoinut sen. Lisäksi kohinasta on tullut erottamaton vastinpari informaatiolle. Hänen mukaansa kohina työntyy aina tavalla tai toisella sinne, missä informaatiota tuotetaan (Mowitt 1987: 194). Äänentutkija Ingo R. Titze kuvaa tätä osuvasti kertoessaan omasta suhtautumisestaan hifi-äänitteillä esiintyviin käheisiin lauluääniin:

\footnotetext{
Mutta juuri kun ääniteteollisuus on kyennyt poistamaan kaiken laitekohinan ja särön, jotkin esiintyjät laittavat kohinaa ja säröä takaisin saundiin omilla äänillään. Nykyisin kuulemme monia moderneja musiikkityylejä, joissa ääni on tarkoituksella ajettu särölle. Kysyn usein itseltäni, miksi tarvitsen hifi-äänitteitä kuullakseni kaiken tämän rahinan ja käheyden? [--] Mutta minä olenkin vanha hupsu. Nuoria kuuntelijoita ei juurikaan näytä häiritsevän äänet, joita minä kutsuisin "epäpuhtaiksi. (Titze 1997.) ${ }^{16}$
}

Äänen jakaminen signaali- ja kohinaosaan mahdollistaa äänessä olevan kohinan tai hälyn tarkastelemisen erotuksena "puhtaasta" äänestä. Äänestä voidaan tietokoneavusteisin mittausmenetelmin "erottaa" periodinen ja epäperiodinen aines, siis ne taajuudet, joilla tapahtuu säännöllistä värähtelyä ja toisaalta ne taajuudet, joissa värähtely on epäsäännöllistä (Laukkanen \& Leino 2001: 176-178). Luonnollisessa ihmisäänessä kohinaa on mukana aina jossain määrin (mts.), ja kohinan todellinen erottaminen äänestä (esimerkiksi käheyden poistaminen nauhoitetusta ihmisäänestä) on hyvin hankalaa. Äänen "halkaiseminen" signaaliosaan ja kohinaosaan onkin vain yksi mahdollinen tapa hahmottaa ääntä ja sitä, mitä se voi "pitää sisällään". Tämä tapa on kuitenkin meille länsimaisille niin totunnainen, että on vaikeaa keksiä muuta mahdollista tapaa. Tämä tulee omassa työssäni esille siinä, että kuunnellessani äänenlaatuja vertaan niitä usein suhteessa laulajan "puhtaasti" soivaan ääneen niin, että käheys, narina ym. näyttäytyvät helposti jonakin, joka on ylimääräistä äänessä-myös sellaisena, joka voi tutkijan mielestä tuoda lisäarvoa ääneen.

Mutta onko käheässä äänessä itsessään jotain ylimääräistä? Maallikkojen keskuudessa tietynlaisesta käheästä tai karkeasta äänestä käytetään usein nimitystä "räkäinen ääni”. Tällöin voidaan ajatella, että äänessä on todellakin jotain ylimääräistä. Jokin limasäie ehkä särisee laulajan ääniväylässä aiheuttaen näkökulmasta riippuen joko 
"coolin" saundin tai luotaantyöntävän efektin. Myös äänihuulikyhmyjen tai muiden pattien ilmaantuminen äänihuuliin tuovat ääneenkin epäilemättä jotakin ylimääräistä. Elizabeth Grosz toteaa (Mary Douglasin ja Julia Kristevan ajatteluun nojaten), että ylimääräiset eritteet ruumiinaukoilla aiheuttavat inhoa, koska reittien ruumiista maailmaan ja päinvastoin tulisi olla puhtaita, jotta vuorovaihto maailman kanssa olisi mahdollista. ${ }^{17}$ (Grosz 1994: 195.) Tätä kautta voidaan ymmärtää myös aiemmin käsitelty äänen hygieenisyysihanne suhteessa käheyteen, sen paljastamaan kudosten rosoisuuteen tai ääniväylän limaisuuteen.

Voimmeko siltikään ajatella käheää ääntä niin kuin sen takana olisi mahdollisimman selkeästi soiva ääni, ja että kaikki äänessä oleva roso vain peittää alleen tuon puhtauden? ${ }^{18}$ Yksi vastaus tutkimukseen liittyviä analyyseja tehdessä voi olla äänen ottaminen sellaisena kuin se on. Olipa ääni sitten kuinka käheä tai vapaa käheyksistä hyvänsä, se tulisi määritellä ja kuvailla yhtä tarkoin. Analysoitaessa tulisi myös olla tarkkana sen suhteen, että "puhdasta" soivaa ääntä ei käsitetä normina ja käheyttä poikkeamana normista. Pikemminkin huomion voi kiinnittää analyyseissa niihin äänenlaadullisiin seikkoihin, jotka nousevat kuuntelukokemuksessa merkityksellisiksi, olivatpa ne sitten kuinka käheää tai "puhdasta" ääntä tahansa.

John Shepherd toteaa, että puhtaatkin äänet ovat laadultaan merkityksellisiä juuri niiden puhtauden vuoksi (Shepherd 1987: 163). Ne eivät ole läpinäkyvä ja neutraali media, jonka avulla viestin voi välittää häiriöttä vastaanottajalle, vaan luovat puhtaudellaan tietynlaista mielikuvaa. Puhdas ääni ikään kuin paljastaa ideaalisesti koko ihmisäänen tai instrumentin äänen sellaisena kuin se on, kaikkine mahdollisine ylä-äänineen. Shepherdin mielestä täydelliset puhtaat äänet voivat kuitenkin olla vieraannuttavia, koska ne tuntuvat sanovan kaiken. Populaarimusiikin "likaiset" äänet puolestaan kutsuvat kuulijan täydentämään itseään ulkoapäin. (Shepherd 1987: 164) Shepherdin näkökulman voi kääntää myös toisinpäin niin, että "likaisessa" äänessä on paljon "tarinaa myös äänen itsensä tasolla" - huojumisia, rosoja, kompastumisia, hengästymisiä jne. Paljon tapahtumia lauluäänen prosodian tasolla, laulajan liikkeiden jälkiä tai äänen murtumakohtia, jotka antavat kuulijalle ruumiillisen kosketuspinnan laulun maailmaan.

Täydellisen puhdas ääni rinnastuu helpommin instrumenttiin ja voi näin ollen merkitä inhimillisyyden tai ruumiillisuuden katoamista, kun taas "inhimillinen", epätäydellinen ja virheellinen ääni voi merkitä aitoutta ja rehellisyyttä. ${ }^{19}$ Äänen kontrolloimattomuus, sen epäpuhtauksien salliminen voi tuoda mieleen myös vapauden, kuten Beth Gibbonsin esimerkissä aiemmin tuli ilmi. Toisaalta täydelliseksi hiottu ja virtuoosimaisiin suorituksiin taipuva äänikin voi ilmentää vapautta - vapautta ruumiista ja sen kömpelyydestä. Kyse on erilaisista retorisista keinoista, jotka toimivat eri musiikkityyleissä. Itse en näe tarpeellisena verrata esimerkiksi klassisen laulamisen ja populaarimusiikin laulamisen tulkinnallista toimivuutta, sillä ne kummatkin eittämättä toimivat omissa konteksteissaan loistavasti. 


\section{Äänen virtaus}

“[...] ihmisääni on ruumiin ääntä kirjaimellisesti” (Frith 1996: 192).

Etsin työssäni fysiologista lähestymistapaa täydentävää näkökulmaa, joka mahdollistaisi äänenlaatujen tarkastelun kokemuksellisesta näkökulmasta ja metaforisemmalla tasolla. Leeuwen (1999) pohtii kirjassaan Speech, Music, Sound äänenladun semiotiikkaa "kokemuksellisen merkityspotentiaalin" näkökulmasta. Hän luonnehtii kokemuksellista merkityspotentiaalia niin, että kuullessamme äänen voimme tietää, miten tuottaisimme kyseisenlaisen äänen itse. Meillä on kyky laajentaa käytännöllistä äänten tuottamisen kykyämme myös metaforiseksi. (Leeuwen 1999: 139-140.) Leeuwenin tarjoama näkökulma mahdollistaa kuulijan ymmärtämisen ruumiillisena olentona, joka ymmärtää äänet ruumiillaan ja suhteessa ruumiiseensa. Kaikki laulumusiikin kuuntelijat eivät ole välttämättä itse laulaneet, eivätkä näin ollen osaisi suoranaisesti tuottaa vastaavanlaista ääntä kuin kuuntelemansa laulaja. Silti heilläkin on kyky myötäelää laulajan liikkeiden laatuja. Esimerkiksi kireää ääntä kuunnellessa myös kuulijan lihakset voivat kiristyä - tai ainakin hän tietää, miltä tuntuu, kun lihakset kiristyvät. Näin hänellä on omakohtainen kokemus kireyteen, vaikka hän ei tätä välttämättä itse edes tiedostaisi. Tällainen kokemus on yksi tärkeimmistä kosketuspinnoista laulajan tulkintaan ja sen ymmärtämiseen.

Leeuwen toteaa, että esimerkiksi kireä ääni ei ainoastaan ole kireä, vaan myös merkitsee kireyttä. Äänen käyttökonteksti värittää tätä kireyttä sitten eteenpäin esimerkiksi aggressioksi tai jännittyneisyydeksi. (Leeuwen 1999: 131.) Kun kuunnellaan laulajan äänenlaatua laulajan tulkinnan näkökulmasta mielenkiintoista onkin, miten äänenlaadut asettuvat suhteessa muihin elementteihin, esimerkiksi kappaleen muuhun soivaan materiaaliin tai sanoihin. Populaarimusiikin laulamisesta on kirjoitettu tähän mennessä pitkälti sosiologisesta näkökulmasta, jolloin erilaisia äänenlaatuja on kytketty erilaisiin kulttuurisiin yhteyksiinsä. ${ }^{20}$ Tällaisissa tarkasteluissa itse äänenlaatujen kuvailu on jäänyt maininnoiksi siitä, miten ääni on "rosoinen", "käheä" tai "rankka". Vaikka tarkastelujen yhteydessä on saatettu pohtia ruumiillisuutta kulttuurisesta näkökulmasta, sen enempää huomiota ei ole kiinnitetty siihen, miten nämä äänet syntyvät laulajan ruumiissa tai miten ne vaikuttavat kuulijaan ruumiillisena olentona. Näkökulma on ollut laajempi, ei yksittäisiin lauluihin, lauluääniin tai yksittäisiin kuuntelukokemuksiin syvällisemmin pureutuva. ${ }^{21}$ Äänenlaatujen analyysin ei kuitenkaan tarvitse jäädä laulajan ääntä yleisesti kuvaavien luonnehdintojen varaan. Sen sijaan voidaan tutkia, miten äänenlaadut syntyvät materiaalisella tasolla ja miten ne toimivat tietyssä (soivassa) ympäristössä osana laulajan tulkintaa. ${ }^{22}$

Aiemmin pohdin puheentutkimuksen kannalta sitä, millaisena käheys konkretisoituu, mistä siinä on materiaalin (kudosten) tasolla kyse. Mutta millaisiin materiaalisiin ja metaforisiin määreisiin se voi liittyä aistimisessamme? Synesteettisessä, 
aistien välisessä tarkastelussaan Leeuwen rinnastaa karkean äänen karkeaan materiaaliin. Hän viittaa Louis Armstrongin karkeaan ääneen ja vertaa sitä ahavoituneisiin kasvoihin, epätasaiseksi rapattuun seinään ja kuluneisiin farkkuihin. (Leeuwen 1999: 132.) Myös äänihuulten kudoksessa olevat "ylimääräiset" patit voidaan rinnastaa karkean materiaalin epäsäännönmukaisuuksiin (esim. pellavakangas, säkkikangas). ${ }^{23}$ Käheys tuo ruumiin (äänihuulten) materiaalisuuden kuulovaikutelmana esille. Äänessä kuuluu "muukin kuin melodiaa soittava ääni". Siinä kuuluu erityisellä tavalla ruumiin sisäosien materia ja sen laatu. Miksi käheydessä sitten kuuluisi ruumiin sisäosien materian laatu paremmin kuin "puhtaassa" äänessä? Onko niin, että "puhtaasta" äänestä ei voi erottaa kuulon avulla jotakin tiettyä ruumiin kohtaa, joka vastustaisi vapaata äänen virtausta? Onko käheiden ja muuten rosoisten äänien kohdalla kyse siis jostakin, joka (fysiologisesti, kokemuksellisesti tai metaforisesti) vastustaa äänen kulkua? Esimerkiksi voidaan ajatella, että narinassa tiiviisti toisiaan vasten painuvat äänihuulet vastustavat vapaata liikettään ja näin "jarruttavat" äänen virtausta. Käheydessä tämä jarruttaminen voi olla passiivisempaa jos se johtuu äänihuulten kyhmyistä, ja aktiivisempaa jos se johtuu esimerkiksi kurkun seudun jännittyneisyydestä. Käheydessä kyse on myös äänen virtauksen hapertumisesta, siitä että ääni huokoistuu ja osittain hajoaa, murtuu tai särkyy. Äänen virtauksella viittaan tässä juuri ääneen ruumiillisen kokemuksen näkökulmasta, en fysiologisen tarkastelun näkökulmasta. ${ }^{24}$

Äänen virtauksen kautta on mahdollista ymmärtää käheä ääni muutoin kuin kerroksellisena kokonaisuutena, joka sisältää signaali- ja kohinaosan tai puhtaan äänen ja sen päällä olevan käheyden. Äänen virtauksen käsitteen avulla hahmotan tasoa, joka liittyy toisaalta ruumiin konkreettisiin liikkeisiin ja toisaalta lauluäänen kuuntelemisessa syntyviin laajempiin merkityksiin. Äänen virtaus kuvaa kuulijan (tai laulajan) ruumiillisen kokemuksen affektiivista tasoa äänestä. Laulajan lauluesityksessä käheys ei ole vain äänihuulten epäsäännöllistä liikettä, mutta se ei ole myöskään passiivista säkkikankaan tai kalkitun seinän omaista materiaalia. Äänen virtauksen näkökulmasta käheys (kuten kaikki äänenlaadut) ovat erottamaton osa elävää ja alati muuttuvaa ääntä. Tarkastelun taso etsiytyy nyt pois fysiologisen ruumiin tasosta. Olennaiseksi nousee liikkeen luonteen tarkastelu, ei yksittäisten ruumiin osien liikkeiden tarkastelu sinällään. Esimerkiksi käheyden tapauksessa ei tästä näkökulmasta ole niinkään mielenkiintoista tehdä tarkkaa analyysia siitä, mitä laulajan ääniväylässä tapahtuu laulamisen aikana. Mielenkiintoista sen sijaan on miten ruumiissa tapahtuu. Laulamisen sykäykset, työnnöt, odotukset jne. ovat äänen virtausta. Miten tahansa laulaja laulaakin, hän ei voi välttyä äänen virtaukselta. Laulaja voi laulaa ilman tunnetta, ilman iloa tai vihaa, mutta silti hänen äänensä ilmentää koko ajan hänen ruumiinsa muuntuvaa (tai staattista) tilaa. "Äänen virtaus" -käsite pohjautuu työssäni oman kuuntelukokemukseni lisäksi Daniel Sternin (1985) "vitaaliaffekti" -käsitteeseen, ${ }^{25}$ joka kuvaa koko ajan olemisessamme läsnä olevia dynaamisia ja alati muuntuvia voimia. 
Siinä missä fysiologinen näkökulma pilkkoo ruumiin ja keskittyy yksittäisten ruumiinosien (esim. äänihuulten) liikkeisiin tai pysäyttää äänen tarkastellakseen sen laatuja staattisina (esim. "ääni on käheä tai nariseva") äänen hahmottaminen virtauksen käsitteen kautta on liikkeen ja muutoksen sallimista. Tämä lähestymistapa hyväksyy tutkimusmateriaalin alituisen muuntumisen ja liikkeen sekä toisaalta myös tutkijan oman kokemuksen muuntuvuuden eri kuuntelukerroilla. Mikään ei enää pysykään paikoillaan tai ole yksiselitteistä. Totta kai tutkija joutuu valitsemaan mitä puolia esittää kuulemastaan, ja tässä mielessä analysoiminen onkin aina yksinkertaistamista ja pysäyttämistä. Virtauksellisuus on laulamisessa ja laulamisen kuuntelemisessa toteutuvan kokonaisvaltaisuuden sallimista. Laulaminen ja kuunteleminen kun ovat parhaimmillaan koko ruumista koskettavia kokemuksia, eivät vain äänihuuliin, suuhun ja korviin liittyviä. Niin laulamisessa kuin toisen ihmisen äänen kuuntelemisessakin tärkeään osaan nousee tietoisuus oman ruumiin sisäosien tilasta ja liikkeestä sekä ruumiin reaktioista toisen ääneen. Fenomenologi Timo Klemola (2005) on todennut, että proprioseptiset aistit, joiden avulla on mahdollista hahmottaa muun muassa ruumiin sisäosien tilaa ja ruumiin asentoja, ovat jääneet länsimaisessa kulttuurissamme vähäiselle huomiolle. Ei siksi, etteikö länsimaisilla ihmisillä olisi näitä aisteja vaan siksi, ettei proprioseptista tietoisuutta täällä juurikaan tarkoituksellisesti harjoiteta, eikä sitä näin ollen herkistytä tuntemaan. (Klemola 2005: 85, 91.) Poikkeuksena tässä näen urheilijoiden ja tanssijoiden lisäksi erityisesti laulajat, jotka kehittävät ruumiinsa sisäosien tuntoaistia sekä lihasten liikkeiden tunnistamisessa että äänen värähtelyjen tuntemisessa. ${ }^{26}$

Äänen virtaus on analyysin esittämisen kannalta haasteellinen. Jos katsomme kuvan 2 transkriptiota, voimme nähdä, että siinä näkyy allekkain musiikintutkimuksellinen näkökulma (nuotit), fonetiikan näkökulma (foneettiset transkriptiot) ja puheentutkimuksen näkökulma (äänenlaatuja kuvaavat merkit). Transkriptiossa on jälkiä kuuntelemisen analyyttisesta päästä. ${ }^{27}$ Siinä näkyy, mitä olen oppinut kuulemaan Björkin äänestä näiden tieteenalojen näkökulmista. Mitä transkriptiossa ei suoraan näy, on kokemus äänen virtauksesta. Se kytkeytyy tosin näihin kaikkiin edellä esitettyihin transkription osiin, mutta ei ole pelkistettävissä yhteenkään niistä. Äänen virtauksen "osia" voi tarkastella yksittäisten liikkeiden (fysiologisesta) näkökulmasta (esimerkiksi "äänihuulet napsahtavat nopeasti kiinni"), ja näin voidaan katsoa, mitkä seikat fysiologisesta näkökulmasta katsottuna ovat mahdollisesti luomassa tuntumaa tietynlaisesta äänen virtauksesta. Transkriptiosta puuttuu kuitenkin vitaaliaffektien taso. Ovatko kuuluvat sisäänhengitykset kiivaita vai herkkiä? Kuinka paljon intensiteettiä on alukkeessa: onko se napsahtava vai kenties räjähtävä? Äänen virtauksen taso tulee työssäni esille vasta transkription selitysvaiheessa. Se yleensä "nuotintuu" vasta kirjoitusvaiheessa fysiologisen ja musiikillisen kertomuksen lomaan, vaikka itse kuuntelemisprosessi saattaakin lähteä liikkeelle juuri laulajan äänen virtauksen myötäelämisestä. Seuraavassa analyysissa olen pyrkinyt erottelemaan kokemuksellista tasoa myös irti muista tarkastelun tasoista (kuvissa 3 ja 4). 


\section{Analyysi II: Björkin laulutulkinta kokemuksellisesta näkökulmasta}

Lähestyn nyt aiemmin fysiologiselta kannalta analysoimaani Björkin lauluääntä kokemuksellisen merkityspotentiaalin ja äänen virtauksen näkökulman avulla. Daniel M. Grimley on aiemmin tehnyt analyysia samaisesta kappaleesta ja toteaa Björkin äänestä analyysinsa yhteydessä, että ääni on taltioitu niin, että se lähenee "lähes täydellistä digitaalista selkeyttä". Itse tallennuslaitteiston kohina on siis minimoitu. Grimley toteaakin, että tämä tuo puolestaan esille Björkin äänen vuotoisuuden ja tätä kautta syntyvän intiimin vaikutelman. (Grimley 2005: 45.) Leeuwenin mukaan nykyinen studioteknologia (mikrofoni ja äänten miksaaminen) mahdollistaa äänen ja kuuntelijan välisen sosiaalisen etäisyyden erottamisen todellisesta etäisyydestä ja äänen voimakkuudesta. Leeuwen toteaa, että juuri äänenlaatu välittää sosiaalista etäisyyttä. Jo Bing Crospyn ja "crooning"-laulamisen ajoista lähtien kuulijalle on tarjottu mahdollisuus uskoa jollain tasolla, että laulajalla on häneen äänen välityksellä henkilökohtainen suhde. Tätä suhdetta Leeuwen kutsuu imaginaariseksi ja tätä läheisyyden/etäisyyden vaikutelmaa äänen ja kuulijan välillä imaginaariseksi etäisyydeksi ${ }^{28}$ (Leeuwen 1999, 24-25).

Björkin Hidden Place -kappaleessa laulun minän ${ }^{29}$ imaginaarinen etäisyys kuulijaan nouseekin yhdeksi laulutulkinnan kantavista voimista. Laulun sanojen tasolla sanallinen minä liikkuu suhteessa kuviteltuihin kuulijoihin. Ensimmäisessä säkeistössä sanallinen minä puhuttelee rakastettuaan: "Through the warmthest cord of care, your love was sent to me [--]". Toisessa säkeistössä sanallinen minä kääntyy sisäänpäin ja puhuu itsekseen tai vaihtoehtoisesti kuulijalle, joka asettuu hyvin lähelle minää: "Now, I have been slightly shy, and I can smell a pinch of hope [--]". Kolmannessa säkeistössä tämä jatkuu: "He's the beautifullest, fragilest, still strong, dark and divine [--]." Kuulija pääsee lähelle sanallista minää, koska tämä kertoo hänelle hyvin paljastavia ja herkkiä asioita itsestään. Kuulijan päästäminen lähelle tapahtuu myös äänellisen minän tasolla: Björkin ääni on varsinkin säkeistöissä vahvasti kompressoitu, jolloin pienetkin henkäykset kuuluvat lähes yhtä voimakkaina kuin itse soiva ääni. Kertosäkeissä studiotekniikalla (kaiulla) luotu tila on suurempi kuin säkeistöjen kaiuttomampi ja intiimimpi tila. Kertosäkeiden tila asettuukin sekä kaiun että Björkin äänenkäytön vuoksi "julkiseksi tilaksi" tai "julistamisen tilaksi". Imaginaarinen etäisyys kuulijaan on suurempi kuin säkeistöissä. Myös kertosäkeiden sisällä tapahtuu liikettä imaginaarisen etäisyyden näkökulmasta. Tällöin kyse ei ole niinkään siitä, tuntuuko äänellinen minä olevan fyysisesti etäämpänä tai kauempana kuulijaa vaan siitä, laulaako (suuntaako hän laulunsa) etäälle vai kauas ja jääkö hän tässä mielessä etäisemmäksi tai läheisemmäksi suhteessa kuulijaan. Seuraavaksi tarkastelen jo aiemmin analysoimiani kahta fraasia kappaleen ensimmäisen kertosäkeen alusta. 


\section{Fraasi $1 \longrightarrow$ Fraasi 2 \\ Julistava Intiimi \\ Etäisempi Läheisempi}

Kuva 3: Ä̈̈nellisen minän ja kuulijan välisen imaginaarisen etäisyyden muutos Björkin Hidden Place-kappaleen ensimmäisen kertosäkeen fraaseissa 1 ja 2.

Kertosäkeessä korkealta laulettu ensimmäinen fraasi on julistava (katso kuvat 2 ja 3 ). Laulun minä haluaa kaikkien tietävän, että hän on menossa rakkaansa kanssa heidän yhteiseen piilopaikkaansa. Matalammalta laulettu "vastausfraasi" tuo taas esille sen, että kyse on salaisuudesta, intiimistä kahden ihmisen välisestä asiasta. Vaikka studioteknisesti tilan tuntu ja laulajan etäisyys (mikrofoniin) ovat samat kummassakin fraasissa, niin silti jälkimmäinen tuntuu kuulijasta läheisemmältä. Tämä johtuu juuri Björkin tavasta laulaa käheällä äänellä - kuin kohti yksittäistä kuulijaa. Julistavat kohdat hän taas laulaa selkeällä ja voimakkaalla, kauas kantavalla äänellä - hän laulaa kaikille, jotka kuuntelevat. Tämä korkeiden fraasien selkeys ja matalien fraasien käheys toistuvat myös kappaleen kahdessa muussa kertosäkeessä. Imaginaarisen etäisyyden lisäksi kertosäkeestä nousee kuuntelukokemuksessa esille myös äänellisen minän asenteen muutos, joka hahmottuu vitaaliaffektien ja äänen virtauksen tasolla erilaisina kokemuksellisina määreinä (katso kuva 4).

$\begin{array}{ll}\text { Fraasi } 1 \longrightarrow & \text { Fraasi } 2 \\ \text { Toteava } & \text { Innostunut } \\ \text { Selkeä, ehjä linja } & \text { Rosoinen, mutkikas } \\ \text { Avoin } & \text { Salaperäinen, sulkeutuva } \\ \text { Vapaa, ilmava } & \text { Tarttuva, takertuva } \\ \text { Suoraselkäinen, pystysuora } & \begin{array}{l}\text { Madaltuva, kyyristyvä, } \\ \text { maata kohti menevä }\end{array}\end{array}$

Kuva 4: Ä̈̈nellisen minän (ruumiillisen) asenteen muutos Björkin Hidden Place -kappaleen ensimmäisen kertosäkeen fraaseissa 1 ja 2.

Seuraavaksi käyn läpi tarkemmin, miten kuvassa 4 esitetyt kokemukselliset määreet linkittyvät Björkin äänen fysiologiseen ja musiikilliseen tasoon. Kertosäkeen ensimmäinen fraasi (katso kuva 2) on neutraali selkeine äänenlaatuineen ja perusilmeineen (vrt. kuva 4: "toteava", "selkeä"). Melodian kaari on tässä fraasissa melko yksinkertainen, ja Björk laulaa sen selkeästi. Tästä syntyy "ehjän linjan" vaikutelma. Tähän vaikutelmaan voi liittyä myös se, että ääni on tässä kohtaa "ehjä" eli se soi kuulaasti ilman rosoja. Vokaalit on lausuttu avoimesti ("avoin", "vapaa") ja ne sijoittuvat suuontelossa melko taakse. Vokaalien avoimuus luo tuntua "vapaudesta": ääni ikään kuin 
virtaa vapaasti ilman, että sen tiellä olisi esteitä. Vokaalien artikulaation takaisuus puolestaan luo mielikuvaa "pystysuoruudesta" ja "suoraselkäisyydestä". Tämä liittyy siihen, että vokaalien lausuminen suuontelon takaosassa luo tuntuman, kuin äänen virtaus olisi pystysuorempi verrattuna etiseen artikulaatioon, jossa äänellä työnnytään tai kurotetaan eteenpäin. "Vapauden" ja "ilmavuuden" tuntua laulamiseen tuovat myös melodiakaaren korkeus (verrattuna toiseen fraasiin), laulamisessa oleva helppouden tuntu ja tilassa syntyvä kaiku.

Ensimmäisen fraasin loppupuolella Björk alkaa liukua hymynomaiseen eleeseen samalla kun hänen suuontelonsa madaltuu fraasin viimeisissä äänteissä. Toisessa fraasissa suuontelo on madaltunut ja vokaalit ovat työntyneenä edemmäs suussa. Melodialinja on matalampi kuin ensimmäisessä fraasissa. Suuontelon madaltuminen ja melodian sävelkorkeudellinen madaltuminen luovat "madaltuvan", "kyyristyvän" ja "maata kohti menevän" tunteen. Asiat eivät tapahdu enää niinkään vertikaalisesti ylöspäin kuin horisontaalisesti ja matalammalla tasolla. Laulaja kurkottaa etisellä artikulaatiolla horisontaalisesti kohti kuulijaa. Avoimuuden tilalle on nyt tullut "salaperäisyys" ja "sulkeutuvuus". Ääni ei virtaa vapaasti vaan kulkee matalamman suuontelon läpi. Laulaja ei avaudu julistamaan vaan "pitää pienempää suuta", kuten kansanomainen metaforinen ilmaus kuuluu. Suuontelon madaltumiseen liittyy hymynomainen ele, joka lisää tulkintaan salaperäisyyden tuntua (salaperäinen hymy).

'That'-sanan mukaantulo toisen faasin alkuun luo pienen kiirehtimisen tunnun kyseiseen fraasiin. Tämä kiirehtiminen tuntuu myös siinä, miten 'go'-sanan viimeinen äänne $[\mathrm{u}]$ tulee aiemmin kuin ensimmäisen fraasin vastaava äänne. Äänellinen minä aivan kuin haluaisi kiirehtiä salaiseen piilopaikkaan menemistä. Samalla salaperäinen hymynomainen ele tuo mukaan innostuneen houkuttelemisen tuntua ("tule, mennään jo, siellä on kivaa - ja siellä on jotain salaperäistä, jännittävää") (vrt. kuva 4: "innostunut"). Äänellinen minä ei siis kiirehdi esimerkiksi epätoivoisesti tai paniikinomaisesti, vaan tietää jo, että tulee ennemmin tai myöhemmin pääsemään piilopaikkaan.

Käheys ja matalammalta laulaminen lisäävät tähän vielä oman kommenttinsa ("mutta pidetään tämä meidän kahden välisenä asiana"). Laulaja ikään kuin hakee mataliin ääniin kuiskaavuuden tuntua, vaikka laulaakin ne melko voimakkaalla intensiteetillä. Houkuttelemisen teema tulee ilmi myös laulun sanojen semanttisella tasolla, sillä juuri ennen ensimmäistä kertosäettä sanallinen minä toteaa: '[I'm] so close to simply calling you up, and simply suggesting..."

Toisessa fraasissa melodialinja on liikkuvampi ("mutkikkaampi") kuin ensimmäisessä fraasissa ja laulajan ääni on käheä ("rosoinen"). Rosoisempi ääni luo mielikuvaa tarttuvammasta materiaalista siinä missä ensimmäisen fraasin ääni oli kuulas, selkeä ja näin ollen "sileämpi". Ensimmäisen fraasin ilmavuuden ja vapauden tilalle on tullut nyt maanläheisyys ja takertuvuus. Toisen fraasin loppupuolella Björk liukuu jo pikku hiljaa takaisempaan ja väljempään artikulaatioon ja valmistautuu näin kertosäkeen kolmanteen fraasiin, joka on taas luonteeltaan avoin. 
Huomioitavaa äänen virtauksen kannalta on se, miten äänenlaadut muuntuvat Björkin tulkinnassa vaivihkaa. On vaikeaa sanoa, milloin hymynomainen ele tarkalleen ottaen alkaa ja milloin toisen fraasin käheyden voi sanoa muuttuvan lieväksi käheydeksi - vai onko ääni tässä kohtaa jo kenties vain vuotoinen. Tämä kertoo siitä, että äänen virtaus, tapa jolla laulajan ruumis elää jatkuvaa affektien virtaa, on alati muuntuva. Kuvien 3 ja 4 esitys on tässä mielessä liian jähmeä ja dikotomisoiva. Aivan kuin tulkinta olisi ensin avointa ja sitten yht'äkkiä salaperäistä. Tässä mielessä fysiologisesta näkökulmasta ja kokemuksellisesta näkökulmasta tehtyjen analyysien esittäminen yhdessä on perusteltua. Fysiologisen ruumiin liikkeiden mikrotason tarkastelulla äänen virtaus voidaan kytkeä ruumiin konkreettisiin liikkeisiin, jolloin vitaaliaffektiset laadut eivät jää ruumiista ja sen ajallisesta elämisestä irrallisiksi laatumääreiksi. Tehdystä analyysista käy myös ilmi, että laulajan lauluäänen laatu asettuu laulutulkinnassa suhteessa useisiin eri tekijöihin. Emme voi analysoida vain lyhyttä fragmenttia liittämättä sitä laulun kokonaisuuteen, tarinaan, joka laulussa kerrotaan. Lisäksi aiheellista olisi kuunnella lauluääntä myös suhteessa kappaleen muihin soiviin elementteihin. Kyseisestä Hidden Place -kappaleesta tällaista analyysia on tehtykin jo aiemmin (ks. Grimley 2005).

Äänihygienian näkökulmasta Björkin tapa käyttää ääntään ei ole ihanteellinen, mutta taiteellisen ilmaisun näkökulmasta se on sitä. Björkin laulannassa äänenlaatujen muutoksilla on merkityksenmuodostuksen kannalta tärkeä rooli, kuten jo aiemmin mainitsin. Tässä mielessä Björk "käyttää" erilaisia äänenlaatuja kommunikoidakseen. Kuitenkaan Björkin tulkinnasta ei tule sellainen vaikutelma, että hän tietoisesti tekisi käheyttä tai muita äänenlaadun muutoksia ääneensä. Tämä kuuluu juuri siinä, miten muutokset äänenlaaduissa eivät tapahdu mekaanisesti esimerkiksi fraasien aluissa, vaan pikemminkin liukuen ja oman monimuotoisemman "logiikkansa" mukaan. Björkin tulkinnasta tulee vaikutelma, että hän ikään kuin päästää käheyttä ääneensä tai sallii äänensä olla käheä. Oman työni kannalta tärkeintä ei olekaan se, mitä Björk on ajatellut tai aistinut laulaessaan vaan se, millaisen mielikuvan tai kokemuksen se luo kuulijalle - eli miten laulutulkinta toimii kuuntelukokemuksessa.

\section{Kulttuurisesti määräytynyt käheys}

Aiemmin käsittelin käheyttä fysiologisen ja kokemuksellisen ruumiin näkökulmista. Näistä kummatkin ovat myös kulttuurisesti määräytyneitä ruumiita. Fysiologiseen ruumiiseen liittyvät ääni-ihanteet ovat tietyn kulttuurin piirissä syntyneitä ihanteita. Kokemuksellinen ruumis kokee ja ymmärtää kuulemaansa aina jossakin kulttuurisessa kontekstissa ja myös suhteessa kyseisen kulttuurin fysiologisella tasolla määriteltyihin ääni-ihanteisiin. Erottelen näistä kahdesta näkökulmasta omakseen kuitenkin kulttuurisesti määräytyvän ruumiin. Siinä missä kaksi ensimmäistä ruumiiseen liittyvää näkö- 
kulmaa laulamiseen lähtevät liikkeelle toinen materiasta ja toinen kokemuksesta, niin kulttuurisesti määräytyvän ruumiin näkökulmasta katsottuna laulamiseen vaikuttavat erityisesti kulttuuriset tekijät. Käsittelen kulttuurisesti määräytyvää ruumista työssäni toistaiseksi hyvin yleisellä tarkastelun tasolla. Tässä artikkelissa näkökulma kyseiseen ruumiskonstruktioon avautuu lähinnä Alan Lomaxiin liittyvien pohdintojen kautta sivuten myös populaarimusiikin tutkimuksessa yleisesti käytettyä genren käsitettä.

Etnomusikologian kentällä yksi tunnetuimpia laulamisen ja kulttuurin yhteyttä käsitelleitä tutkijoita on Alan Lomax, jonka näkemykset tiivistyvät hänen teoksissaan Folk Song Style and Culture (1968) ja Cantometrics (1976). ${ }^{31}$ Vaikka Lomaxin massiivinen tutkimus maailman laulutyyleistä saikin aikoinaan kritiikkiä osakseen, ${ }^{32}$ puoltaa se silti paikkaansa tässä tarkastelussa. Lomax tarkastelee laulamista nimenomaan esityksissä - siis soivaa lauluääntä, myös äänenlaatuja. Oman työni kannalta kiintoisaksi Lomaxin tutkimuksen tekee myös se, että hänkin lähestyy laulajien äänenlaatuja kuuntelemisen menetelmällä. Näkökulma kulttuurisesti määräytyvään ruumiiseen on tullut tähän artikkeliin Lomaxin käsittelyn kautta, vaikka Lomax ei juuri ruumista käsittelekään eksplisiittisesti omassa työssään. Hänen näkökulmassaan on selvästi tausta-ajatuksena, että kulttuurin rakenteet määräävät yksilön toimintaa (ja näin ollen myös yksilöllisten ruumiiden toimintaa, esimerkiksi lauluäänen tuottamisen tapoja).

Cantometrics teoksessaan Alan Lomax luokittelee käheyden (hoarseness), karkeuden (harshness), narisevuuden (grating) ja surinan (buzzing) samaan luokkaan, jolle hän antaa nimen rahina (rasp). Hän erottelee ja jättää luokastaan kuitenkin pois äärimmäiset ja patologiset tapaukset. Lomax toteaa myös, että 'rahina'-luokasta voisi yhtä hyvin käyttää termiä 'karkeus'. (Lomax 1976: 220) Lomax luokittelee karkeuden seuraavasti: äärimmäinen karkeus ('extreme rasp'), voimakas karkeus ('great rasp'), ajoittainen karkeus ('intermittent rasp'), vähäinen karkeus ('slight'), ei karkeutta ('none'). Luokittelu toimii hyvin lähtökohtana karkeuden analyysille tai analysoitaessa suuria määriä erilaisia karkeita ääniä. Kuten Lomax itsekin toteaa, tarkemmalla analyysilla päästäisiin paremmin käsiksi erityyppisiin karkeuksiin. (Lomax 1976: 220.) Lomaxin työssä ei olekaan kyse yksittäisten äänenlaatujen tarkasta erottelusta ja niiden nyanssien tunnistamisesta vaan mahdollisimman monen erilaisen muuttujan huomioimisesta lauluesityksessä. Tässä mielessä Lomaxin tarjoama malli voi toimia hyvin tutkijan "tarkistuslistana", jonka avulla hän voi katsoa, ettei omasta tutkimusmateriaalista ole tullut sivuutettua joitakin lauluesityksen ulottuvuuksia, jotka saattavatkin osoittautua myöhemmin hedelmällisiksi.

Karkeutta esiintyy Lomaxin tutkimuksen mukaan kulttuureissa, joissa on sosiaalista hajautumista. Sen sijaan yhtenäisissä kulttuureissa karkeuden tyyppiset melut "vaimennetaan" pois lauluesityksistä. (Erickson 1968: 205.) Lomaxin mukaan karkeus liitetään yleensä erityisen voimakkaaseen äänenkäyttöön. Kuitenkin alkuperäiskansojen keskuudessa karkeaa ääntä esiintyy myös rennossa äänenkäytössä, jonka tarkoituksena saattaa usein olla eläinmäisen murinan ja karjumisen tuottaminen. Tämä 
liittyy Lomaxin mukaan samaistumiseen eläinmaailman kanssa. Kulttuurisessa tarkastelussaan Lomax toteaa, että karkea äänenkäyttö liittyy itsetuntoon. Kulttuureissa, joissa lapset kasvatetaan vahvan itsetunnon omaaviksi, karkeus on yleisempää. Hän myös toteaa, että karkeus on yleisempää miehillä kuin naisilla. Siellä, missä naisetkin laulavat karkealla äänellä he ovat yleensä tasa-arvoisempia suhteessa miehiin sekä sosiaalisesti että taloudellisesti. (Lomax 1976: 122, 220).

Voidaanko Lomaxin ajatusten valossa siis sanoa, että karkea rocklaulaminen manifestoi itsetuntoa, uskallusta haistattaa pitkät muulle yhteiskunnalle? Entä onko rocklaulajan äänen pakko olla käheä tai karkea, jotta se olisi uskottava omassa kulttuurisessa kontekstissaan? Liittyykö naisten karkean äänenkäytön lisääntyminen rockkulttuurin tasa-arvoistumiseen? Nämä ovat liian laajoja kysymyksiä käsiteltäväksi tässä, mutta myös populaarimusiikin tutkimuksen puolella on tehty analyyseja siitä, miten laulajien lauluäänet ja -tavat viestivät yhteiskunnan tyypillisistä sukupuolirooleista. Esimerkiksi John Shepherd (1987) tarkastelee laulajien äänenlaatuja suhteessa kulttuurisiin sukupuolistereotypioihin. Hänen mukaansa "cock"-rockissa käytettävä karkea ääni kuvastaa miehistä seksuaalisuutta ja sulkee pois pehmeämpien äänentuottotapojen myötä myös naiseuden. "Soft"-rockissa puolestaan nainen esiintyy pehmeän äänensä kanssa hoivaavana hahmona ja miespuolinen pehmeästi laulava laulaja puolestaan "naapurinpoikana". Shepherdin mukaan "cock"-rock näyttäytyy äänentuottotapansakin puolesta miehisenä äänen sijoittuessa enemmän laulajan päähän, kun taas "soft"-rokissa käytetään enemmän rintakehän (sydämen alueen) värähtelyjä tuotettaessa pehmeää ja täyteläistä ääntä. (Shepherd 1987: 165-170.)

Yksi Lomaxin tutkimuksen lähtökohdista on se, että laulutapamme on "yksi vähiten yksilöllinen aspekti persoonallisuudessamme" (Pantaleoni 1972: 158). Laulaminen yhdistää ihmisen muihin samankaltaisiin ihmisiin pikemmin kuin erottaa hänet erilaiseksi yksilöksi. Laulamisessa on olennaista yhteisen tyylin jakaminen muun yhteisön kanssa. (Pantaleoni 1972: 158.) Lomax toteaakin, että tällainen näkökulma saattaa järkyttää niitä, jotka ajattelevat laulamista juuri yksilöllisen kokemisen näkökulmasta. Mutta hän muistuttaa, että vaikka musiikista nauttisikin yksinäisyydessä, musiikki silti jäsentyy tietyn kulttuurin tyylin mukaisesti ja näin valmistaa kuuntelevan yksilön kohtaamaan tämän kulttuurin julkisetkin puolet. Lomaxin mukaan laulajat sopeutuvat siihen, mitä muut kulttuurin jäsenet heiltä odottavat, eli laulavat kulttuurin tyylinormien mukaisesti. Laulaminen on pitkälti standardisoitua toimintaa ja olennaista siinä on yhteisen kokemuksen jakaminen niin esiintyjien kuin kuulijoidenkin kesken. (Lomax 1976: 11-17.)

Vaikka lähestyn (yksittäisen) laulajan tulkintoja (yksilöllisen) kokemuksen näkökulmasta, myös omassa työssäni on taustalla ajatus siitä, että laulamisessa on paljon yhteisesti jaettua. Tämä ei kuitenkaan liity työssäni siihen, miten "yläpuolella oleva" kulttuuri tai abstraktit "rakenteet" määräävät yksilöiden toimintaa, vaan siihen, miten yksilöt ymmärtävät toisiaan ruumiillisella tasolla, konkreettisessa kanssakäymisessä. 
Ajattelen yksilöiden tuottamien ja vastaanottamien (affektiivisen ja ruumiillisten) virtojen muodostavan elävät käytännöt, jotka eivät ole koskaan täysin pelkistettävissä kategorioihin, laulamisen tapauksessa esimerkiksi tyyli- tai genrekategorioihin. Silti tutkija voi abstrahoida näistä käytännöistä kategorioita, ja niin on usein tehtykin. Sen sijaan, että kulttuurisesti määräytyvää ruumista käyttäisi tutkimuksessa apuna todistaakseen laajalla mittakaavalla laulutyylien ja muiden kulttuurin ilmenemismuotojen vastaavuuksia, niin sitä voi käyttää välineenä ymmärtää laulamiseen liittyviä kulttuurisia asenteita - myös sitä, miten nämä asenteet toimivat yksilöiden ja yksittäisten ruumiiden tasolla.

Siinä missä äänenlaatujen fysiologinen tarkastelu lähestyy ääntä tuottavaa ruumista "ulkoapäin", Lomaxin kulttuurinen lähestymistapa lähestyy laulukulttuureja ulkoapäin. ${ }^{33}$ Lomaxin lähestymistavan ja siihen liittämäni kulttuurisesti määräytyvän ruumiin voi nähdä olevan lähellä Alexa Schriempfin määrittelemää sosiaalista mallia. Tässä mallissa sivuutetaan helposti niin biologia kuin yksilöllisyyskin. (Schriempf 2001: 59.) Adriana Cavarero esittää kirjassaan For More Than One Voice (2005), että ihmisäänten ruumiillinen erityisyys, jokaisen ihmisen äänen erilaisuus ja jäljentämättömyys on sivuutettu yleisemmin myös filosofian historiassa. Sen sijaan ollaan keskitytty semanttiseen ja samalla tavoiteltu "abstraktia ja ruumiitonta universaaliutta", näkökulmaa, jossa sana ei ole sidoksissa kurkkuun tai lihaan. (Cavarero 2005: 2.) Äänten yksilöllisyys on sivuutettu myös ääneen kohdistuvissa tutkimuksissa siinä mielessä, että nämä tutkimukset ovat yleensä selvityksiä siitä, mikä on oikeaa tai hyvää äänelle (Cavarero 2005: 8). Vaikka tutkimuksissa ääni ymmärretäänkin ruumiiseen sidoksissa olevana, silti se esittäytyy "kaikkien äänenä ja ei kenenkään äänenä" (Cavarero 2005: 11). Tässä mielessä näen mielekkäänä tutkia laulamista, joka sijoittuu "omaan laulukulttuuriini". Tällöin näen tutkittavan laulajan ensisijaisesti pikemminkin persoonana (yksilönä) kuin esimerkiksi jonkin genren edustajana. Tällöin on myös pakko myöntää oma osallisuutensa, se että kyseisen laulajan tulkinnat koskettavat myös itseä ja että olen itsekin vain yksi ruumiillinen toimija muiden joukossa, en muiden toimintaa "ylhäältä tai ulkoapäin" tarkkaileva irrallinen tai objektiivinen havainnoija. Laulukulttuuri lävistää myös tutkijan ruumiin, ja tämä tulee erityisen hyvin esille tutkimusmateriaalia kuunneltaessa.

Lauluäänen laatua on luonnollisesti tarkasteltu myös populaarimusiikkia käsittelevissä tutkimuksissa. Niissä lauluäänen piirteitä on tarkasteltu usein suhteessa genreen, johon tarkasteltavien laulajien katsotaan kuuluvan (esim. edellä esitelty Shepherdin "cock"-rock tarkastelu). Populaarimusiikin laulajien äänenlaadut ovat saaneet joissakin tarkasteluissa osakseen tarkempaa mikrotason analyysia (esim. Välimäki 2005: 301-327), mutta yleensä niitä on kuvailtu yleisemmällä tasolla (esim. Moore 2000; Potter 1998). Monesti laulajan tunneilmaisua selittävissä kommenteissa tukeudutaan käsitteisiin, jotka asettuvat Sternin (1985) käsitettä käyttääkseni "kategoristen affektien" (ilo, suru, kaipuu jne.) alueelle. Nämä usein jo sanallistetut ja vakiintuneet 
tunteiden muodot kuvaavat tietyllä (kulttuurisella) tarkastelun tasolla hyvin laulajan tulkintaa. Jotkut ovat kuitenkin ottaneet tästä askeleen pidemmälle kohti "vitaaliaffektista" kuvailemisen tapaa. ${ }^{34}$ Esimerkiksi Tarja Rautiainen (2001) kuvailee laulajien ääniä mielestäni myös vitaaliaffektisesti, vaikkei hän sitä suoranaisesti tekstissään tuokaan esille. ${ }^{35}$ Hän käyttää muun muassa seuraavanlaisia luonnehdintoja: "pehmeä, intiimiyttä tavoitteleva laulutyyli", "”venyttelevä" laulutapa", "laiska artikulaatio", "'honottava' ääni", "täysjänteisen rintaäänen käyttö", "'pakotettu' ääni" (Rautiainen 2001: 187, 189, 215, 269). Nämä luonnehdinnat kertovat jotain olennaista laulajan ruumiillisesta olemisen tavasta. Ne eivät suoranaisesti liity tunteisiin, mutta voivat silti olla merkityksellistettyjen tunteiden rakennusaineita.

Miksi laulamista tulee lähestyä myös virtauksen näkökulmasta? Eikö riitä, että toteaa: laulaja ilmentää tässä kaipausta vibratolla? Se, mitä ajan takaa, on yksilöllisempi näkökulma. Vaikka kulttuurisesti olisimme sopineet, että vibrato fraasin lopussa tietyn tyylilajin lauluissa kuvastaa kaipausta, haluan silti tietää, millainen juuri tämän tässä laulavan hahmon kaipaus on. Riutuuko hän kaipauksessa vai onko kaipaus kevyttä ja kaihoisaa? Tällä tarkkuuden tasolla genren määrittämä äänenlaatujen "tunnekoodisto" ei välttämättä riitä. Työssäni olennaista ei olekaan genren tyylipiirteiden kartoittaminen ja erotteleminen materiaalista, vaan pikemminkin uudenlaisen tiedontuottamisen tavan löytäminen, jossa laulamista ja lauluäänen kuuntelemista voidaan lähestyä ajassa elävänä ja virtaavana tapahtumana. Tämä tapahtuu niin myötäelämällä tutkimusmateriaalia empaattisesti kuin menemällä tarkastelussa mikrotasollekin, jossa paljastuu äänen suora kytkös ruumiin liikkeisiin. Vaikka lauluäänen piirteiden "genreyttäminen" eli kytkeminen genreyhteyksiinsä ei kuulukaan varsinaisesti työhöni, tulen työssäni kuitenkin vielä myöhemmin palaamaan genren käsitteeseen ja sen mahdollistamiin näköaloihin.

\section{Analyysi III: Kulttuurisia huomioita Björkin äänestä}

Voimmeko Lomaxin tutkimuksen valossa sanoa, että Björkin äänen käheys määräytyy osittain hänen islantilaisesta kulttuuritaustastaan? Björk tuo vahvasti esille islantilaisen identiteettinsä haastatteluissaan. Joitakin yhteyksiä Lomaxin väittämiin voidaan Björkin äänestä toki löytää. Björkille tyypilliset tehokeinoina toimivat kovat alukkeet ja äänen ajoittainen karkeus voidaan nähdä suhteessa Lomaxin toteamukseen: "Glottaali- tai kurkkuäänteillä koristelu ja karkeus ovat [--] erityisesti luonteenomaisia metsästys- ja kalastuskulttuureiden laulajille" (Lomax 1976, 26). Asia ei kuitenkaan ole näin yksinkertainen. Björkin laulutyyli on muotoutunut toki suhteessa hänen identiteettiinsä islantilaisena, perinteisen kalastuskulttuurin jäsenenä. Mutta yhtä lailla hänellä on musiikilliset juurensa punkin parissa. Lisäksi hänellä on yksilönä takanaan elämänkokemus, jonka monet eri tekijät ovat muovanneet hänen laulutyyliään. Loma- 
xiin nojaava väite jää siis hyvin hataralle pohjalle. Oman työni kannalta ongelmallista Lomaxin lähestymistavan kaltaisessa näkökulmassa onkin sen abstraktius. Hänen tarkastelunsa liikkuu sellaisella tasolla, että siitä on vaikea vetää uskottavia johtopäätöksiä yksittäisiin tapauksiin. ${ }^{36}$

Yleisellä populaarimusiikin tarkastelun tasolla käheyden voidaan kuulla ilmentävän seksuaalisuutta ehkä juuri intiimin imaginaarisen etäisyytensä vuoksi. Intiimiyden lisäksi myös käheyden ylenmääräinen ruumiillisuus verrattuna instrumentaalisempaan "puhtaaseen" ääneen voi liittää käheyden seksuaalisuuteen. Tämä ei kuitenkaan tarkoita sitä, että käheys välttämättä ilmentäisi seksuaalisuutta yksittäisissä laulutulkinnoissa ja kuuntelukokemuksissa. Kategoriset äänenlaatujen kulttuurisia merkityksiä kuvaavat määritelmät voivat viedä tulkintojen tekemisen lauluäänistä liian jähmeään suuntaan. Voisiko Björkin äänen käheys tässä kuitenkin kertoa siitä, että äänellinen minä vihjaa salaiseen piilopaikkaan menemisen sisältävän seksuaalista latausta? Vai kertooko käheys vain siitä, että piilopaikkaan menijä haluaa viattomasti jakaa salaisuuden kuulijan kanssa ja sen vuoksi käyttää salaisuuden kertomiseen sopivaa ääntä: imaginaarisesti läheistä käheyttä? Hidden Place -kappaleen kontekstissa meille selviää, että kyseessä on naisen tai tytön ihastus poikaa tai miestä kohtaan. Vespertine-levyä kuunneltaessa voidaan levyn toinen kappale Cocoon ajatella jatkumoksi tämän ensimmäisen kappaleen (Hidden Place) tarinalle. Cocoonissa nainen ja mies ovat löytäneet yhteisen paikkansa, Björk laulaa: "He slides inside / Half awake half asleep / We faint back into sleephood / When I wake up the second time in his arms / gorgeousness: he's still inside me !!!!!” Siis hyvin selkeästi seksuaalista aktia kuvaava esitys, jonka Björk laulaa erittäin vuotoisella, jopa ilmaa ulospäin puskevalla äänellä.

Silti lapsenomaisesti innostuneelta tuntuva hymy Hidden Place -kappaleen käheästi lauletussa kohdassa vie kuulijan aivan muualle kuin seksuaalisia merkityksiä löytävään tulkintaan. Tässä piilee mielestäni Björkin laulutulkintojen toimivuuden yksi salaisuus: hän luo ristiriitaisuuksia ja epäloogisuuksia tulkintoihin äänellään. Tässä hän eroaa monista muista (populaarimusiikin) laulajista, jotka luottavat ilmaisussaan maneerien voimaan. "Maneerilaulamisessa" käheys on seksikkyyttä (tai vanhemmalla laulajalla elettyä elämää) kuvaava piirre, vibrato kuvaa liikuttumista, narina sisäistä ristiriitaa ${ }^{37}$ ja niin edelleen. Monilla laulajilla äänenlaadut esiintyvät myös aina tietyissä musiikin rakenteellisissa kohdissa: esim. vibrato lähes jokaisen fraasin lopussa. Jos käheyden liittää Björkin tulkinnassa seksuaalisuuteen, se ei ole kuitenkaan kategorisiin määritelmiin sopivaa seksuaalisuutta. Ei iäkkäämmän naisen tummaa ja ehkä kohtalokastakin seksuaalisuutta tai nuoren naisen epävarmaa ja viatonta seksuaalisuutta. Pikemminkin se on kujeilevaa, leikkisää ja merkillisellä tavalla salaperäistäkin. 


\section{Laulajan valinta vai materiaalinen/kulttuurinen pakko?}

Käheys on siitä mielenkiintoinen äänenlaatu, että sitä on vaikea tuottaa tietoisesti (laulu)ääneen. Esimerkiksi narina, vuotoisuus tai nasaalisuus ovat paljon "helpompia" äänenlaatuja tässä mielessä. Laulajan kokemukseni on, että käheys tulee ja menee, kuten tahtoo. Jos laulutilanteessa on virittäytynyt tarpeeksi herkäksi, niin käheys pääsee tulemaan juuri niihin oikeisiin kohtiin tulkintaa, jossa se on tehokkaimmillaan. Käheyden tietoinen laittaminen ääneen luo helposti laulamiseen epäautenttisuuden tunnun - useat meistä ovat varmasti kuulleet esimerkiksi lauluesityksiä, joissa laulaja yrittää olla väkisin "rock" yrittäen laulaa käheästi. Tämä lienee yksi suurimpia "etikettivirheitä", joita rockin laulaja voi tehdä.

Käheys asettuu laulajan oman tahdon, kulttuurin ja materian rajapintaan. Näitä käheyteen vaikuttavia eri puolia onkin käytännössä vaikea erottaa toisistaan. Laulaja voi mahdollisesti halutessaan valita käheyden tietoisesti. Hän voi jopa vaalia sitä, kuten esimerkiksi iskelmälaulaja Kirka on tehnyt jättämällä väliin äänensä ohjatun kouluttamisen. Hän toteaa: "Musta tuntuu, että jokin tuoreus tai originaalisuus, se omin juttu, kärinä, olisi voinut tuhoutua, jos olisin hakenut paljon oppia ääneen ja muutenkin" (Babitzin \& Kinnunen 1999: 72). ${ }^{38}$ Mutta yhtälailla laulajan tekemään valintaan on voinut samalla vaikuttaa myös kulttuurin muovaama asenne, esimerkiksi toisten laulajien tarjoamat tyyliesikuvat. Laulaja on voinut tehdä valintansa myös vastoin oman kulttuurinsa ääni-ihanteita. Kirkan tapauksessa esikuvien äänet ja oman kulttuurin ihanteet ovat olleet ristiriidassa keskenään:

On kiva törmätä tuohon asiaan uudestaan ja uudestaan. Että miten sä laulat, ja ei noin voi laulaa. Eihän kukaan mene sanomaan Bruce Springsteenille tai Little Richardille, että tuolla lailla laulaen ääni ei kestä vuottakaan. Ero on siinä, että sellainen äänenkäyttötapa on niin amerikkalais-englantilainen, ettei se siellä saa uumoilemaan tuhoa. Meillä on totuttu kaunolaulantaan ja slaavilaistyyppiseen melankoliaan. (Babitzin ja Kinnunen 73: 1999)

Laulajan tahtoa on voinut kulttuuristen asenteiden lisäksi olla muovaamassa myös materiaalinen taso. Laulaja oppii tulemaan toimeen äänensä kanssa sellaisena kuin se on, kaikkine rosoineen ja käheyksineen. Ja usein käy tietysti niinkin, että materian taso ei anna periksi laulajan tahdolle eikä miellytä laulajaa - tällöin laulaja voi kokea äänensä käheytymisen hyvinkin vaikeana asiana. Se voi häiritä tulkintaa ja kaventaa näin laulajan kommunikoinnin ja ammatinharjoittamisen mahdollisuuksia. Vaikka ruumiin materia voikin näyttäytyä jonkinlaisena fyysisenä reunaehtona, niin fysiologinenkaan ruumis ei ole muuttumaton perusta tai pohja, jonka päälle kulttuuriset toimintatavat rakentuvat. Schriempf kutsuu tällaista ajattelua, jossa kulttuurisen aineksen ajatellaan rakentuvan biologisten faktojen päälle, materialismiksi. Tässä mallissa ongelmana on hänen mukaansa se, että biologia nähdään siinä valmiiksi annettuna ja itsessään 
merkityksettömänä. Tässä mielessä malli ei eroa aiemmin esitellystä sosiaalisesta mallista. (Schriempf 2001: 61-63)

Schriempf ehdottaa rumiillisuuden tarkasteluun interaktionistista, vuorovaikutteista mallia, jossa ruumis nähdään aina jo kulttuurisena ja aina jo materiaalisena (Schriepf 2001: 68). Ruumiit eivät ole millään tasollaan tai missään vaiheessa esisosiaalisia tai esikulttuurisia ja toisaalta mitkään sosiaaliset tai kulttuuriset käytännöt eivät ole irrotettavissa materiaalisuudesta. Näin myöskään ei ole olemassa tieteellisin menetelmin löydettävää objektiivista totuutta ruumiista, vaan siihen kietoutuu aina myös jo kulttuurinen puolensa. Schriempf toteaa, että vaikka kulttuuristen ja biologisten seikkojen välille voikin tehdä eroja ja erotteluja, niin näiden erojen ei tarvitse olla dikotomisia, vaan ne voivat olla monimutkaisten suhteiden vuorovaikutusten tarkastelua. ${ }^{39}$ (Schriepf 2001: 68-70.) Se, että laulaja valitsee levylleen tulkinnan, jossa hänen äänensä on käheä, voi olla yhtä aikaa sekä materiaalinen, kulttuurinen että yksilöllinenkin valinta. Nämä kaikki tasot risteävät ja sulautuvat toisiinsa monimuotoisilla tavoilla, jolloin ne eivät enää hahmotukaan välttämättä erillisinä tasoina vaan esimerkiksi "alkujaankin sekoittuvina, samaa maailmaa asuttavina modaliteetteina - eräänlaisina todellisuuden ja sen tuotannon laatueroina", kuten Katve-Kaisa Kontturi ja Milla Tiainen osuvasti toteavat tulkitessaan feministiajattelija Elisabeth Groszin näkemyksiä materiaalisuudesta ja diskursiivisuudesta (Kontturi ja Tiainen 2004:17).

Myös fysiologisten tarkastelujen sisällä ollaan herätelty kysymyksiä materian muovautuvuudesta ja mukautuvuudesta. Laukkanen pohtii sitä, voiko ääntä harjoittaessa oppimista tapahtua myös solutasolla:

\footnotetext{
Kudos myös reagoi käytölle ja ympäristöolosuhteille. [--] Viimeaikainen solu- ja molekyylibiologinen tutkimus on tuottanut tuloksia, joiden mukaan ulkoiset tekijät kuten kudokseen kohdistuva mekaaninen kuormitus (solun venytys, altistaminen tärinälle) voi vaikuttaa solujen geeniekspressioon ja siten siihen, millaisia proteiineja solussa muodostuu.[--] Eräänä tulevaisuuden visiona on selvittää, voidaanko äänen harjoittamisella vaikuttaa äänihuulikudoksen biomekaanisiin ominaisuuksiin ja jos, niin millainen harjoitus parantaisi äänenlaatua ja lisäisi äänihuulikudoksen kestävyyttä eniten. (Laukkanen 2002.)
}

Laulajat tietävät, että laulaminen, sen harjoitteleminen ja siinä edistyminen vaativat kehon muovautumista osiltaan uudenlaiseksi myös materian tasolla (lihasten toimintatavat, asennot jne). Ajatus siitä, että tämä muovautuminen voisi tapahtua solutasolla asti, on hyvin kiehtova. Tällöin voidaan todellakin sanoa, että laulamisen kulttuuriset käytännöt ja ruumiin materia ovat kietoutuneina toisiinsa, erottamattomasti yhtä. Laulutapa muokkaa soluja ja lihaksia, jotka puolestaan tarjoavat laulamiselle ja sen liikkeille tietynlaisen (materiaalisen) toteutumisen mahdollisuuden. 


\section{Lopuksi}

Olen lähestynyt lauluäänen laatua tässä artikkelissa fysiologisen, kokemuksellisen ja kulttuurisesti määräytyvän ruumiin näkökulmista. Fysiologinen ruumis edustaa länsimaisen (lääke)tieteen piirissä syntynyttä käsitystä ihmisruumiista. Kulttuurisesti määräytyvä ruumis pohjautuu ajatukseen siitä, että ruumis ja sen tapa toimia määräytyvät kulttuurista käsin. Tämä näkökulma on ominainen antropologisille ja sosiologisille tieteille. Kokemuksellinen ruumis on tässä ja nyt oleva minun elävä ruumiini, kuten fenomenologisen ajattelun piirissä asia ilmaistaan.

Kaikissa näissä edellä mainituissa näkökulmissa on omat ongelmansa. Fysiologisen ruumiin näkökulman taustalla on ajatuksia siitä, että ihmisruumista voidaan tarkastella "objektiivisesti" ulkoapäin ja että ruumis sinällään voisi olla kulttuurirajat ylittävä "pohja" tai materia, jonka varaan kulttuuriset käytännöt rakentuvat. Kulttuurisesti määräytyvän ruumiin ongelmana voi helposti olla sen abstraktius, jolloin se ei kosketa tosiasiallisia arjen (kulttuurisia) tekoja ja materiaalisia ruumiita. Kokemuksellisen ruumiin näkökulma voi puolestaan "sulkeutua itseensä" niin, että kytkennät laajempiin kulttuurisiin yhteyksiin voi jäädä tekemättä. Kaikissa näissä näkökulmissa on myös hyvät puolensa. Fysiologisen ruumiin näkökulma tarjoaa jo valmiina olevaa tutkimustietoa ruumiista ja äänestä. Menetelmän (kuuntelemisen) tasolla tämä näkökulma tarjoaa tarkkuutta ja erottelukykyä. Kokemuksellinen ruumis tarjoaa ymmärtävän ja sisäisen näkökulman vastapainona kahden muun näkökulman ulkoisuudelle. Kulttuurisesti määräytyvän ruumiin näkökulman avulla voidaan kytkeä fysiologiset ja kokemukselliset tarkastelut laajemmalle tasolle, jossa on jo ennalta sanallistettua tietoa siitä, mitä mitkäkin asiat laulamisessa merkitsevät. Tätä kulttuurisesti määräytyvän ruumiin dialogia kahden muun ruumiskonstruktion kanssa aion viedä pidemmälle tutkimukseni edetessä.

Shriempfin näkemys siitä, että ruumis on aina sekä kulttuurinen että materiaalinen, toimii hyvin myös käheyttä tarkasteltaessa. Lisään Shriempfin näkemykseen vielä sen, että ruumis on aina myös kokemuksellinen. Ja kokemus on puolestaan kietoutunut yhteen materiaalisten ja kulttuuristen seikkojen kanssa. Artikkelini tarkoituksena on ollut avata tuoreita tarkastelukulmia lauluääneen. Lähinnä tämä on tapahtunut tarkastelemalla lauluääntä sulkematta tarkastelua vain yhden tieteenalan tai ihmiskäsityksen piiriin. Äänen virtauksellisuuden ja laulajan ruumiin materiaalisuuden esilletuomiseksi olen nivonut erilaisia tutkimusmenetelmiä ja paradigmoja tavalla, joka osin ylittää luonnontieteiden ja ihmistieteiden ihmiskäsitysten välillä olevan kuilun. Näenkin erilaiset ihmiskäsitykset tässä pikemminkin toisiaan täydentävinä kuin keskenään riitelevinä - teoreettisen tason ristiriidoistaan huolimatta.

Johan Fornäs (1998) korostaa sitä, että inhimillinen todellisuus on itsessään monimuotoinen ja ristiriitainen. Näin ollen myös erilaiset todellisuutta rekonstruoivat teoriatkin voivat olla keskenään ristiriitaisia. Fornäs kannustaa tutkijoita avoimuuteen 
erilaisia teorioita kohtaan - tutkimukselle on hyödyksi, jos pystyy välillä vaihtamaan näkökulmaa. Hän toteaa, että perinteiden välille voi muodostaa dialogia ja kommunikaatiota ilman, että perinteiden välisiä eroja tarvitsisi silotella. Tutkijan näkökulma tutkittavaan aiheeseen on kuitenkin aina osittainen, ${ }^{40}$ näin on, vaikka näkökulmia olisi useampiakin. Fornäs kirjoittaa: "kukin teoreettinen malli on kuin valokiila, joka valaisee jotakin [tutkittavan] kohteen tärkeää puolta" (Fornäs 1998: 19-23).

Tutkija voi positiotaan vaihtamalla tarkastella tutkimaansa lauluääntä "moniulotteisesti" kiinnittymättä yhdenlaiseen tapaan tarkastella ja kokea. Itse en ole halunnut sulkea mitään näistä käsitellyistä tietämisen muodoista pois tutkimuksestani. Kuuleminen ja lauluäänen kokeminen eivät lokeroidu itsestään vain yhteen näkökulmaan, vaan ne ovat kokonaisvaltaisia. Työssäni eri ruumiskonstruktiot voivat näyttäytyä teorian tasolla erillisinä ja ristiriitaisina, mutta itse menetelmän tasolla (kuuntelemisessa) ne sulautuvat toisiinsa. Monimuotoisen kuuntelemisen eri puolia voidaan erotella toisistaan, löytää erilaisia juonteita kokonaisuudesta ja liittää näiden juonteiden kautta syntyvää tietoa ja ymmärrystä eri tieteenperinteiden ajatuksiin. Ruumiskonstruktiot työssäni edustavat juuri näitä näköaloja eri tieteenperinteisiin, niiden käsitteisiin ja menetelmiin. Samalla ruumiskonstruktiot toimivat valokiiloina omaan tutkimusmateriaaliini ja ajatteluuni. Niiden avulla voin jäsentää erityyppisiä tietämisen ja ymmärtämisen muotoja ja niiden suhteita toisiinsa. Yhtenä lähtökohtana työssäni onkin ollut lisätä ymmärrystä ja tietoa laulajasta ja kuuntelijasta juuri ruumiillisina olentoina ja katsoa, millaiseksi tämä ymmärrys ja tieto muotoutuvat, kun niitä kehitetään tieteen kentällä.

"Minulla on toistuva uni

Aina kun tunnen käheyttä

Nielen lämpimiä hehkuvia valoja

Joita äitini ja poikani leipoivat minulle"

(Björk - Heirloom, Vespertine 2001)

\section{Viitteet}

1 Mielestäni on tärkeää kehittää tutkimusta, jossa hyödynnetään sekä luonnon- että ihmistieteiden tapoja tuottaa tietoa. Tutkimuksen sisälle syntyvä "hankaus" erilaisten tiedontuottamisen tapojen välillä voi olla hedelmällistä: se voi tuoda esille uudenlaisia seikkoja niin tutkittavasta aiheesta kuin myös itse tiedon tuottamisestakin. Kun tarkastellaan erilaisten lähestymistapojen toimimista yhdessä, voidaan nähdä selkeämmin käytännössä niiden heikkoudet ja vahvuudet - sekä niiden ristiriitaisuudet. Esimerkiksi Mikko Lehtonen (2005) on esittänyt kieltä ja ruumista koskevia näkemyksiä, jotka ylittävät luonnontieteiden ja ihmistieteiden välisen kuilun. Hänen tarkastelunsa liikkuu kulttuurintutkimuksen kentällä, johon katson myös oman työni linkittyvän.

2 Puheentutkimus on monitieteinen ala. Keskityn tässä artikkelissa vain muutamaan, oman työni kannalta keskeiseen teokseen, jotka sijoittuvat puheopin, vokologian, puhetekniikan ja fonetiikan kentälle. En siis pyri luomaan kattavaa katsausta käheydestä koko puheentutkimuksen näkökulmasta. Edellä mainituista aloista erityisesti vokologian (äänen tutkimus ja harjoittaminen) piirissä tutkitaan myös lauluääntä. Puheentutkimuksen eri alojen suhteesta toisiinsa, katso Laukkanen ja Leino 2001: 12-13. Kiitän Anne-Maria Laukkasta Tampereen yliopiston Puheopin laitokselta tähän artikkeliin liittyvistä kommenteista ja tarkennuksista. 
3 Tämä artikkeli on osa väitöskirjatyötäni, jossa lähestyn laulutulkintoja muun muassa lauluäänen laadun näkökulmasta.

4 Esimerkkeinä mainittakoon tässä vokologian puolella tehdyistä lauluäänen analyyseista Bestebreurtje et al. 2000, Cleveland et al. 1997, Sundberg et al. 1999 ja Thalén 2001 sekä etnomusikologian puolella puheentutkimuksen piirissä kehitettyjä menetelmiä hyödyntäviä tutkimuksia Eerola 2003 ja 2004 sekä Harvilahti \& Kazagaceva 2003.

5 Äänen akustisiin tutkimusmenetelmiin kuuluu tietokoneavusteisesti tehtäviä analyyseja äänen eri muuttujista. Tutkittaessa länsimaista populaarimusiikin laulamista akustisten tutkimusmenetelmien käyttö on useissa tapauksissa hankalaa, koska soivassa materiaalissa on mukana lauluäänen lisäksi yleensä myös muita (soitinten) ääniä, jotka häiritsisivät mittausten tekemistä.

6 Käheyden tarkempaan analyysiin käytetään puheentutkimuksen puolella GRBAS-asteikkoa, jossa on määriteltynä seuraavat muuttujat: $G$ = grade eli äänen poikkeavuuden aste, $R=$ roughness eli karheus, $B=$ breathiness eli turbulenssihäly (aiheuttajana epätäydellisesti sulkeutuva äänirako), $\mathrm{A}=$ asthenity eli voimattomuus ja $\mathrm{S}=$ strainedness eli puristeisuus. Tarkempaa tietoa GRBAS-asteikosta, katso esim. Hirano 1981. Omassa työssäni en mene näin yksityiskohtaiseen käheyden analyysiin.

7 Patologisoinnista yleisemmin kulttuurisen vallankäytön välineenä, katso Sontag (1978).

8 Itse muistan haltioituneeni ensimmäisellä vokologian luennollani tajutessani, että ne seikat, joita pidin tutkimani laulajan (Björkin) äänessä ja ilmaisussa kaikkein kiehtovimpina, saivat termit ja määritelmät, joiden avulla pystyin hahmottamaan hänen äänensä piirteitä yhä tarkemmin.

9 Analyyseja Björkin lauluäänestä, katso Tarvainen 2004, 2005 ja 2006.

${ }^{10}$ Olen erotellut äänen vuotoisuuden tässä ilman työntämisestä tai valumisesta ulos jälkimmäisten kuvatessa voimakkaampaa ulospäin työntyvää ilmavirtaa kuin mitä on vuotoisessa äänessä. Vuotoisessa äänessä äänihuulet eivät sulkeudu missään värähtelyjensä vaiheessa kokonaan vaan niiden väliin jää rako, josta pääsee purkautumaan ilmaa. Tämä aiheuttaa ääneen kuultavan ilman kohinan. Käheys eroaa vuotoisesta äänestä siten, että siinä on äänihuulten väliin jäävän raon aiheuttaman ilman karkaamisen lisäksi myös äänihuulten värähtelyn epäsäännöllisyyttä, joka tuo ääneen myös rahinaa tai karkeutta.

11 Äänteitä kuvaavat foneettiset merkit ovat pääosin International Phonetic Alphabet (IPA) -järjestelmän mukaiset. IPA-järjestelmään kuuluu myös äänenlaatuja kuvaavia merkkejä. Olen kuitenkin päätynyt käyttämään omaa äänenlaatujen merkitsemistapaani tässä, jotta saan äänenlaatujen kestot ja niiden suhteen musiikin aikaan paremmin esille. Kiitän Michael O’Dellia Tampereen yliopiston Kieli- ja käännöstieteiden laitokselta kommenteista liittyen foneettiseen transkriptioon.

${ }^{12}$ Hygieeninen = terveysopillinen, terveydenhoidon vaatimusten mukainen (Aikio \& Vornanen 1993: 271).

${ }^{13}$ Douglas käyttää tässä yhteydessä 'uskonto' -termiä, vaikka jako länsimaisiin ei-uskonnollisiin ja muiden kulttuurien uskonnollisiin, ei-rationaalisiin näkemyksin tuntuukin nykyaikana jähmeältä. Hygieenisyyskäsitysten voidaankin ajatella liittyvän yleisemmin ja laajemmin maailmankatsomuksiin.

14 Jacques Attali puolestaan muistuttaa, että jo kauan ennen kuin kohinan (noise) käsitettä on teoretisoitu, on häly koettu "tuhona, epäjärjestyksenä, saasteena, aggressiona koodeja muodostavia viestejä kohtaan" (Attali 1977/1985: 27).

${ }^{15}$ Käsittelen puheentutkimukseen ja populaarimusiikin laulamiseen liittyviä käsityksiä käheydestä rinnakkain tässä artikkelissa, koska nämä kummatkin alueet ovat työssäni läsnä.

16 Äänitteen omien ominaisuuksien läpikuultavuuden periaatteesta (hi-fi) ja sen suhteesta esityksen ominaisuuksiin, katso esim. Heikkinen (2005).

${ }^{17}$ En lähde viemään tätä ajatusta tässä pidemmälle Kristevan abjektin käsitteeseen saakka. Lauluäänen abjektista laatua ovat pohtineet aiemmin esimerkiksi David Schwarz (1997: 133-163) ja Susanna Välimäki (2006).

18 Vaikka tutkija sulkeistaisi kuuntelukokemuksessaan mahdollisimman paljon pois kulttuurin tarjoamia "totuuksia" lauluäänestä, voivat ne silti vaikuttaa laulamisen vastaanottoon juuri ruumiin tasolla. Laulaja ja kuuntelija kun elävät tietynlaisessa liikkeellisessä ympäristössä, jossa ruumis on tottunut tietynlaisiin tapoihin olla ja tehdä. Näiden tapojen kokeminen "uutena" on tutkijalle haaste, samoin kuin on näihin tapoihin liittyvien kulttuuristen merkitysten näkeminen uusista näkökulmista.

${ }^{19}$ Kiitos näistä huomioista Anne-Maria Laukkaselle.

${ }^{20}$ Simon Frith kritisoi artikkelissaan "Towards an Aesthetic of Popular Music" (1987) sitä, että klassisen musiikin esteettiset teoriat ovat luonteeltaan pitkälti ei-sosiologisia, kun taas populaarimusiikkia on käsitelty lähinnä vain sosiologisten teorioiden valossa. Viime vuosina tämä jako on kuitenkin alkanut muuttua.

${ }^{21}$ Potter (1998) lähestyy kirjassaan Vocal Authority myös yksittäisiä lauluja ja lauluääniä sekä joitakin niiden piirteitä, mutta ei mene analyysissaan äänenlaatujen mikrotasolle. Marko Aho (2005) on tutkinut Olavi Virran ääntä myös sen mikrotasolla.

${ }^{22}$ Leeuwenkaan ei jätä äänten analyysiaan adjektiivisten luonnehdintojen varaan, vaan näkee tärkeänä myös sen, että katsotaan, miten äänet syntyvät materiaalisella tasolla. (Leeuwen 1999: 130.) 
${ }^{23}$ Susan McClary käyttää puolestaan klassisen musiikin standardisoidusta ja täydellisestä ääni-ihanteesta metaforaa, jossa hän kuvailee äänen pintaa särkymättömäksi ja kiillotetuksi (McClary 1985: 152).

${ }^{24}$ Olen aiemmin kirjoittanut äänen virtauksesta Björkin Undo-kappaleen analyysin yhteydessä (katso Tarvainen 2005: 81).

25 Olen jo aiemmin kirjoittanut Sternin vitaaliaffektin käsitteestä työni yhteydessä (katso Tarvainen 2005: 67 ja 71).

26 Johan Sundberg toteaa kirjassaan The Science of the Singing Voice (1987: 160), että mitä pidemmälle laulaja edistyy, sitä vähemmän hän on riippuvainen siitä, miten hän kuulee oman äänensä. Sen sijaan hän oppii yhä paremmin tuntemaan, miten hänen äänensä värähtelee hänen ruumiissaan ja luottamaan tähän tuntemukseen laulaessaan.

${ }^{27}$ Empaattinen ja analyyttinen kuunteleminen ovat työssäni keskeisiä käsitteitä (katso Tarvainen 2005: 69-72). Toisen ihmisen (laulajan) ruumiinliikkeiden myötäeläminen kuuntelemisessa on osa empaattista kuuntelemista, kun taas fysiologisten ja musiikillisten ainesten havainnoiminen materiaalista on analyyttista kuuntelemista. Empaattinen ja analyyttinen kuunteleminen ovat jatkumo ja käytännössä ne usein kietoutuvat erottamattomasti toisiinsa.

${ }^{28}$ Leeuwen luokittelee imaginaarisen ja todellisen etäisyyden tasot seuraavasti: intiimi etäisyys, henkilökohtainen etäisyys, epämuodollinen etäisyys, muodollinen etäisyys ja julkinen etäisyys. Intiimiin etäisyyteen kuuluu esimerkiksi kuiskaaminen tai erittäin pehmeän äänen käyttäminen kun taas julkiseen etäisyyteen kuuluu maksimaalisen voimakas äänenkäyttö. (Leeuwen 1999: 27.)

29 Sanojen tasolla toimivasta sanallisesta minästä (tai runon minästä), laulajan äänen tasolla toimivasta äänellisestä minästä ja näiden yhdessä muodostamasta laulun minästä, katso Tarvainen 2005: 72-75 ja 2006: 254.

30 Takaisen artikulaation "pystysuoruus" ja etisen artikulaation "eteenpäin työntyvyys" voivat liittyä siihen, miten soiva äänipatsas muotoutuu ääniväylässä, jonka muoto on erilainen takaisessa ja etisessä artikulaatiossa. Se voi liittyä myös siihen kokemukseen, että etisessä artikulaatiossa suun etuosa toimii aktiivisemmin kun taas takaisessa suun takaosa on aktiivisempi. On kuitenkin muistettava, että "äänen virtaus" liittyy kokemukseen, eikä sillä ole välttämättä aina yhtymäkohtia siihen, mitä ääniväylässä fysiologisesta näkökulmasta tarkasteltuna tapahtuu. Suoraselkäisyys ja takainen artikulaatio voivat yhdistyä assosiatiivisesti senkin vuoksi, että klassisessa perinteessä laulajat laulavat usein hyvin takaisella artikulaatiolla ja suoraselkäisessä asennossa.

${ }^{31}$ Lomaxin kantometristä analyysitapaa on viime aikoina soveltanut esimerkiksi Laura Henriksson (2002) kuplettilaulua käsittelevässä pro gradu -työssään.

${ }^{32}$ Monet olivat sitä mieltä, että Lomaxin tarkastelemat nauhoitteet eivät olleet määrällisesti riittäviä, jotta niiden perusteella olisi voinut tehdä niin yleistäviä tulkintoja, kuin mitä hän teki. Lisäksi kysymyksiä herätti se, millä perusteella Lomax oli valinnut ääninäytteet työhönsä. Katso esim. Nettl 1970, Feld 1984 ja Pantaleoni 1972.

33 Pantaleoni on kritisoinut Lomaxin tutkimusta siitä, että siinä arvioidaan muiden kulttuurien musiikkia länsimaisin korvin (Pantaleoni 1972: 159). Länsimainen korva ei osaa välttämättä kuunnella oikeita (kyseisen kulttuurin jäsenille merkityksellisiä seikkoja) itselle vieraasta musiikkityylistä. Siksi kyse ei olekaan laulutyylien tarkastelusta sinällään vaan siitä, miltä ne kuulostavat länsimaisen ihmisen korvaan. Työstä tulee Pantaleonin mukaan tämän vuoksi etnosentrinen. (Pantaleoni 1972: 159.)

${ }^{34}$ Vitaaliaffektit ovat Sternin (1985) mukaan varsinaisten tunteiden (kategoristen affektien) esiasteita. Ne, mitä ymmärrämme arkikielenkäytössä tunteina (ilo, suru jne.) ovat yleensä hetkittäisiä ja saavat alkunsa vitaaliaffektien jatkuvasti läsnä olevasta ja muuntuvasta "virrasta".

35 Tosin Rautiainen tuo kirjassaan esille musiikin ei-kielellisen merkitysmaailman (2001: 62-65), jonka voi katsoa liittyvän kiinteästi myös vitaaliaffektiseen tasoon.

${ }^{36}$ Lomaxin yleistykset ovat kyseenalaistuneet myös yksittäisten kulttuurien tarkastelun tasolla. Steven Feld tutki omassa työssään 500 laulunäytettä yhdestä kulttuurista (Kaluli) ja totesi, että kulttuurinsisäistä vaihtelevuutta oli niin paljon, että olisi ollut mahdotonta luoda kyseiselle kulttuurille yhtä yhtenäistä laulutyylikuvausta. (Feld 1984: 385) Lomaxin väitteitä on puolestaan intialaisen musiikin parissa testannut Edward O. Henry, joka kiinnitti huomiota muun muassa kompleksisimpien yhteiskuntien suureen alakulttuurien kirjoon (Henry 1976: 64).

37 Viittaan tässä monien populaarimusiikin laulajien, varsinkin naislaulajien, tapaan "narisuttaa" ääntään aina fraasien aluissa varsinkin, jos kyseessä on ihmissuhdeongelmista kertova kappale.

${ }^{38}$ Laulunopettajan työssäni olen usein törmännyt oppilailta tulevaan kysymykseen: Voinko laulaa enää "rankasti”, jos koulutan ääntäni? Vastauksena tähän voi sanoa, että esimerkiksi äänen "rankkuuden" voi tuottaa monella eri tavalla, myös niin, että se on fysiologisesti vähemmän rasittavaa.

39 Tässä Schriempf nojaa Nancy Tuanan (2001) ajatuksiin. Tuanan ajatukset ovat Schriempfin artikkelin taustalla muutenkin. Esimerkiksi "interaktionismi"-termi on peräisin Tuanalta (1996, 2001). Feministiseen ajattelun perinteeseen kytkeytyvää materiaalisuuskeskustelua ovat käsitelleet laajemmin Katve-Kaisa Kontturi ja Milla Tiainen artikkelissaan "Taiteentutkimus ja materiaalisuuden haaste" (Kontturi \& Tiainen 2004).

40 Tutkijan näkökulman osittaisuudesta, katso myös Koivunen \& Liljeström 1996. 


\section{Tutkimusmateriaali}

Björk (2001) Hidden Place. Levyllä: Vespertine. Björk Overseas Ltd./ One Little Indian Ltd. CD-levy. Gibbons, Beth \& Rustin Man (2002) Out of Season. Go Beat Ltd. CD-levy.

\section{Lähteet}

Aho, Marko (2005) Laulu Irenelle. Olavi Virta, eleet ja tulkinta. Etnomusikologian vuosikirja 17. Ss. 72-93.

Aikio, Annukka \& Vornanen, Rauni (1993) Uusi sivistyssanakirja. Helsinki: Kustannusosakeyhtiö Otava.

Attali, Jacques (1977/1985) Noise. The Political Economy of Music. Transl. Massumi, Brian. Minneapolis: University of Minnesota Press.

Babitzin, Kirill \& Kinnunen, Raila (1999) Enimmäkseen kirkasta. Helsinki: WSOY.

Bestebreurtje, Martine E. \& Schutte, Harm. (2000) "Resonance strategies for the belting style: Results of a single female subject study". Journal of Voice 14, no 2. Ss. 194-204.

Cavarero, Adriana (2003/2005) For More than One Voice. Toward a Philosophy of Vocal Expression. Kottman, Paul A. (käänt.). Stanford: Stanford University Press. [Orig. A più voci: Per una filosofia dell'espressione vocale.]

Cleveland, Thomas F. \& R. E. (Ed) Stone, Jr. \& Sundberg, Johan \& Iwarsson, Jenny (1997) "Estimated subglottal pressure in six professional country singers". Journal of Voice 11, no 4. Ss. 403-409.

Douglas, Mary (1966/2000): Puhtaus ja vaara. Ritualistisen rajanvedon analyysi. Blom, Virpi \& Hazard, Kaarina (suom.). Tampere: Vastapaino. [Orig. Purity and Danger. An Analysis of the Concepts of Pollution and Taboo.]

Durga, S. A. K. (1983) "Indian Literature on Vocal Abuse". Asian Music, Vol. 15, No. 1, ss. 1-10.

Eerola, Jari (2003) "Laulujen kuvaajat. Spektrianalyysiohjelmat kansanlaulujen tutkimisen apuvälineinä”. Musiikin suunta 3. Ss. 33-44.

Eerola, Jari (2004) "Mikä tekee pajosta pajon? Vepsäläisten lyhyiden pajojen äänentuotollisten tyylipiirteiden kuvaus tietokoneavusteisen musiikintutkimuksen menetelmin". Etnomusikologian vuosikirja 16. Ss. 116-136.

Erickson, Edwin E. (1968) "Self-Assertion, Sex Role, and Vocal Rasp". Teoksessa: Lomax, Alan: Folk Song Style and Culture. Washington, D.C.: American Association for the Advancement of Science. Publication No. 88.

Eriksson, Kai (2003) "Kohina ja kommunikaatio". Tiede ja edistys 4. Ss. 279-292.

Feld, Steven (1984) "Sound Structure as Social Structure". Ethnomusicology, Vol. 28, No.3. Ss. 383-409.

Fornäs, Johan (1998/1995) Kulttuuriteoria. Lehtonen, Mikko, Hazard, Kaarina, Blom, Virpi \& Herkman, Juha (suom.). Lehtonen, Mikko (toim.). Tampere: Vastapaino.

Frith, Simon (1987) Towards an Aesthetic of Popular Music. Teoksessa: Music and Society: The Politics of Composition, Performance and Reception. Leppert, Richard \& McClary, Susan (eds.). Cambridge: Cambridge University Press. Ss. 133-149.

Frith, Simon (1996) Performing Rites. On the Value of Popular Music. Cambridge, Massachusetts: Harvard University Press.

Gray, G. W. \& Wise, C. M. (1959) The Bases of Speech ( $3^{\text {rd }}$ edn). New York: Harper.

Grénman, Reidar (1999) “Kurkunpään pahanlaatuiset kasvaimet”. Teoksessa: Karma, Pekka, Nuutinen, Juhani, Puhakka, Heikki, Vilkman, Erkki, Virolainen, Erkki, Ylikoski, Jukka \& Ramsay, Hans (toim.) Korva-, nenä- ja kurkkutaudit sekä foniatrian perusteet. Helsinki: Yliopistopaino. Ss. 215-217.

Grimley, Daniel M. (2005)" Hidden Places: Hyper-realism in Björk's Vespertine and Dancer in the Dark." Twentiethcentury Music. Volume 2, issue 1. Cambridge: Cambridge University Press. Ss. 37-51.

Grosz, Elizabeth (1994) Volatile Bodies. Toward a Corporeal Feminism. Bloomington \& Indianapolis: Indiana University Press.

Harvilahti, Lauri \& Kazagaceva, Zoja S. (2003) The Holy Mountain. Studies on Upper Altay Oral Poetry. Helsinki: Suomalainen Tiedeakatemia.

Heikkinen, Olli (2005) Sämplätyn rahinan ironia ja nostalgia. Musiikki 3. Ss. 3-14.

Henriksson, Laura (2002) Juha Vainio kuplettiperinteen jatkajana. Pro gradu -tutkielma. Helsingin yliopisto, Taiteiden tutkimuksen laitos, Musiikkitiede.

Henry, Edward O. (1976) The Variety of Music in a North Indian Village: Reassessing Cantometrics. Ethnomusicology, Vol. 20, No. 1. Ss. 49-66.

Hirano, M. (1981) Clinical examination of voice. Teoksessa: Arnold, GE. \& Winckel, F. \& Wyke, BD. (toim.) Disorders of Human Communication 5. Wien: Springer. Ss. 81-84.

Hollien, Harry (2000) “The Concept of Ideal Voice Quality”. Teoksessa: Kent, Raymond D. \& Ball, Martin J. (eds.) Voice Quality Measurement. San Diego: Singular Publishing Group. Ss. 13-24.

Klemola, Timo (2005) Taidon filosofia - filosofin taito. Tampere: Tampere University Press. 
Koivunen, Anu \& Liljeström, Marianne (1996) "Paikantuminen". Teoksessa: Avainsanat. 10 askelta feministiseen tutkimukseen. Toim. Anu Koivunen \& Marianne Liljeström. Tampere: Vastapaino. Ss. 271-292.

Kontturi, Katve-Kaisa \& Tiainen, Milla (2004) "Taiteentutkimus ja materiaalisuuden haaste. Feministisiä suunnanavauksia". Kulttuurintutkimus 21,3. Ss. 17-27.

Laukkanen, Anne Maria \& Leino, Timo (2001) Ihmeellinen ihmisääni. Ä̈̈nenkäytön ja puhetekniikan perusteet, arviointi, mittaaminen ja kehittäminen. Helsinki: Gaudeamus.

Laukkanen, Anne Maria (2002) Vokologia - ihmisäänen tutkimus ja harjoittaminen. Tiivistelmä puhetekniikan ja vokologian professori Anne-Maria Laukkasen virkaanastujaisesitelmästä Tampereen yliopistossa 29.11.2002. http://www.uta.fi/ajankohtaista/tiedotteet/2002/laukkanen.html (luettu 24.6.2006).

Laver, John (1980): The Phonetic Description of Voice Quality. Cambridge: Cambridge University Press.

Leder, Drew (toim.) (1992) The Body in Medical Thought and Practice. Dordrecht: Kluwer Academic Publishers.

Leeuwen, Theo van (1999) Speech, Music, Sound. London: Macmillan Press Ltd.

Lehtonen, Mikko (2005) "Ruumiin ylösnousemus - ja sen haasteet kulttuurintutkimukselle". Kulttuurintutkimus 22: 2. Ss. $15-30$.

Lomax, Alan (1968) Folk Song Style and Culture. Washington, D.C.: American Association for the Advancement of Science. Publication No. 88.

Lomax, Alan (1976) Cantometrics. An Approach to the Anthropology of Music. Berkeley: The University of California Extension Media Center.

McClary, Susan (1985) "Afterword. The Politics of Silence and Sound". Teoksessa: Attali, Jacques (1977/1985) Noise. The Political Economy of Music. Transl. Massumi, Brian. Minneapolis: University of Minnesota Press. Ss. 149-158.

Moore, John (2000) “"The Hieroglyphics of Love': The Torch Singers and Interpretation”. Teoksessa: Middleton, Richard (toim.) Reading Pop. Approaches to textual Analysis in Popular Music. Oxford: Oxford University Press. Ss. 262-296.

Mowitt, John (1987) "The sound of music in the era of its electronic reproducibility". Teoksessa: Leppert, Richard \& McClary, Susan (toim.) Music and Society. The politics of composition, performance and reception. Cambridge: Cambridge University Press. Ss. 173-197.

Nettl, Bruno (1970) "Folk Song Style and Culture. Review". American Anthropologist, New Series, Vol. 72, No. 2. Ss. 438-441.

Pantaleoni, Hewitt (1972) "Folk Song Style and Culture. Review”. Yearbook of the International Folk Music Council, Vol. 4, 25 ${ }^{\text {th }}$ Anniversary Issue. Ss. 158-161.

Potter, John (1998) Vocal Authority. Singing Style and Ideology. Cambridge: Cambridge University Press.

Rautiainen, Tarja (2001) Pop, protesti, laulu. Korkean ja matalan murroksia 1960-luvun suomalaisessa populaarimusiikissa. Tampere: Tampere University Press.

Rihkanen, Heikki (1999) Äänihuulten hyvänlaatuiset muutokset. Teoksessa: Karma, Pekka, Nuutinen, Juhani, Puhakka, Heikki, Vilkman, Erkki, Virolainen, Erkki, Ylikoski, Jukka \& Ramsay, Hans (toim.) Korva-, nenä-ja kurkkutaudit sekä foniatrian perusteet. Helsinki: yliopistopaino. Ss. 212-215.

Schriempf, Alexa (2001) "(Re)fusing the Amputated Body: An Interactionist Bridge for Feminism and Disability". Hypatia. Journal of Feminist Philosophy. Vol. 16, number 4. Ss. 53-79.

Schwarz, David (1997) Listening Subjects. Music Psychoanalysis, Culture. Durham \& London: Duke University Press.

Shepherd, John (1987) "Music and male hegemony". Teoksessa: Leppert, Richard \& McClary, Susan (toim.) Music and Society. The politics of composition, performance and reception. Cambridge: Cambridge University Press. Ss. 151-172.

Sontag, Susan (1983) Illness as Metaphor. Harmondsworth \& Middlesex: Penguin Books.

Stern, Daniel (1985) The Interpersonal World of the Infant. A View from Psychoanalysis and Developmental Psychology. New York, NY: Basic Books.

Sundberg, Johan (1987) The Science of the Singing Voice. Illinois: Northern Illinois University Press.

Sundberg, Johan \& Cleveland Thomas E. \&, Stone, Jr, R. E. \& Iwarsson Jenny S. (1999) "Voice source characteristics in six premier country singers". Journal of Voice 13, no 2. Ss. 168-183.

Tarvainen, Anne (2004) "Laulaminen liikkeenä". Musiikin suunta 3. Ss. 5-15.

Tarvainen, Anne (2005) '"'Between me and myself": Äänellisen minän muotoutuminen Björkin kappaleessa Undo". Musiikki 3. Ss. 66-91.

Tarvainen, Anne (2006) "Björk ja lihan arvoitus: Soiva tulkinta e. e. cummingsin runosta 'I Will Wade Out'”. Teoksessa: Ääniä äänien takaa: Tulkintoja rock-lyriikasta. Toim. Toni Lahtinen \& Markku Lehtimäki. Tampere: Tampere University Press. Ss. 253-270.

Thalén, Margareta \& Sundberg, Johan (2001): "Describing different styles of singing: A comparison of a female singer's voice source in 'Classical', 'Pop', 'Jazz' and 'Blues'. Logopedics Phoniatrics Vocology, Vol. 26 Issue 2 . Ss. $82-93$.

Titze, Ingo R. (1997) "Noise in the Voice". Science for Singers: A Series of Voice Research Columns by Ingo R. Titze. www.ncvs.org/ncvs/info/singers/noise.pdf(Luettu: 14.6.2006). Alunperin julkaistu lehdessä The Journal of Singing, May/June 1997. 
Tuana, Nancy (1996) Fleshing gender, sexing the body: Refiguring the sex/gender distinction. The Southern Journal of Philosophy: Rethinking Sex and Gender 35 (supplement).

Tuana, Nancy (2001) Material locations: An interactionist alternative to realism/social constructivism. Teoksessa: Engendering rationalities. Morgen, Sandra \& Tuana, Nancy (eds.). New York: SUNY Press.

Van Riper, C. \& Irwin, J. V. (1958) Voice and Articulation. Englewood Cliffs: Prentice-Hall.

Välimäki, Susanna (2005) Subject Strategies in Music. A Psychoanalytic Approach to Musical Signification. Acta Semiotica Fennica XXII. Approaches to Musical Semiotics 9. Imatra: International Semiotics Institute, Semiotic Society of Finland.

Välimäki, Susanna (2006) Psykoanalyysi ja musiikin affektit. Seminaariesitelmä. Affektit, soinnit ja kulttuuriteoria -seminaari. Turku. 23.5.2006.

Zemlin, W.R. (1964) Speech and hearing science. Illinois: Stipes. 